\title{
Las cartas de Pedro Estala a Juan Pablo Forner (nueva edición crítica)
}

\author{
María Elena Arenas Cruz \\ I. E. S. Berenguela de Castilla
}

CES.XVIII, núm.19 (2009), págs. 89-142. 
Resumen: Se presenta la primera edición crítica del epistolario entre Estala y Forner, en la que se procede al cotejo de las ediciones de Pérez de Guzmán y Leopoldo Augusto de Cueto y se datan y anotan las veintiuna cartas. Éstas, que sabemos ahora redactadas entre 1789 y 1795, suponen un testimonio fundamental para la historia literaria y política del último tercio del siglo.

Palabras clave: Pedro Estala. Juan Pablo Forner. Epistolario. 
La primera de las cartas de este pequeño epistolario está fechada el 12 de octubre de 1789 en Salamanca, tres meses después de que estallara la Revolución francesa. La última es de junio de 1795, cuando Forner duda de la sinceridad y lealtad del que siempre había sido uno de sus mejores amigos. Veintiuna cartas en seis años resultan un número demasiado reducido, por lo que no es difícil aceptar que sin duda fueron muchas más las misivas, hoy perdidas, que el helenista manchego debió de dirigir al fiscal de la Audiencia de Sevilla, al menos hasta 1797, fecha de la muerte de éste. Pero con ser pocas, no por ello dejan de ofrecer un conjunto de datos y pequeños detalles especialmente curiosos, no sólo en cuanto a los avatares personales y privados de la vida de Estala (su oculta vida amorosa, sus crisis de melancolía o fastidio, su sentido del humor, su pasión por el estudio), sino también en otros aspectos de carácter más general. Uno de ellos, evidentemente, es el relacionado con la amistad, tanto la que unió a los protagonistas entre sí como la que delatan las constantes alusiones a los amigos comunes, entre los que se cuentan Meléndez Valdés, Leandro Moratín, José Iglesias de la Casa o Francisco Bernabéu, entre los más conocidos. La amistad, con todas sus expresiones de afecto y lealtad, pero también con sus juegos de traiciones y mentiras.

Otro de los aspectos más interesantes de este breve epistolario es la información preciosa que encierra "para la historia literaria del último tercio del siglo XVIII», algo que claramente vio Juan Pérez de Guzmán cuando añadió este subtítulo a la copia que del mismo preparó en $1911^{1}$. No podemos olvidar que la mayoría de los personajes que aparecen en estas cartas han vivido su juventud en un ambiente de apertura y relativa libertad de opinión, pues en la década de los ochenta los periódicos abundaban y las leyes que prohibían la lectura de ciertos libros estaban bastante relajadas. Salamanca y Madrid los vieron trotar sus calles y cafés; leían mucho, escribían mucho y se reían y polemizaban con los escritores consagrados, conscientes de que eran una generación estudiosa y entusiasta llamada a transformar la literatura, la jurisprudencia, la historia, la

1 Cfr. J. Pérez de Guzmán, «Veintiuna cartas inéditas de D. Pedro Estala dirigidas a D. Juan Pablo Forner, bajo el nombre arcádico Damón para la historia literaria del último tercio del siglo XVIII», en Boletín de la Real Academia de la Historia. Informes, t. LVIII, I (enero, 1911), págs. 5-36. Esta edición se puede consultar digitalizada en la biblioteca virtual Cervantes. 
educación. Aunque sus primeros proyectos literarios y altas ambiciones profesionales empiezan a recibir apoyo institucional en estos años, será la muerte de Carlos III, en diciembre de 1788, la que marque el inicio del cambio hacia su madurez vital e intelectual. Es, por tanto, a partir de la década de los noventa y al amparo del todopoderoso Godoy, cuando van a alcanzar cierto protagonismo social y literario. Son muchos los datos que en este sentido se desprenden de las cartas de Estala, entre ellos, la publicación de sus traducciones del griego o los avatares de su versión de la República literaria; los triunfos teatrales de Moratín y sus accidentados viajes; los intentos de Forner para publicar sus libelos y sus vanos esfuerzos para que otras obras de mayor calado vean la luz; la polémica suscitada en torno a la representación en Madrid del Filósofo enamorado, de lamentables consecuencias para la amistad que nuestros protagonistas se profesaban; la importancia de los mecenas en toda empresa literaria y profesional en la que se empeñaran, etcétera.

El tercer aspecto que las cartas dejan entrever es la compleja situación política de España en la última década del siglo. A propósito de esto resulta sorprendente comprobar que lo que no se dice, lo que oportunamente se calla, es más que lo que abierta y francamente se discute. Como el resto de los ciudadanos, los protagonistas de estas cartas sufren las diversas formas de represión y censura que se pusieron en marcha para evitar que se repitieran los horrores vividos en el país vecino. Después de 1789 la monarquía empieza a ver que los ideales reformistas ilustrados, los que precisamente defendían estos jóvenes escritores, pueden ser uno de los caminos para la destrucción del sistema autoritario en que se sostenía; se alía, por tanto, con la Inquisición, que vuelve a ganar todos los puestos perdidos en los años en que Carlos III había propiciado una tímida apertura a las luces. A lo largo del lustro que nos ocupa se empieza a hacer patente la contradicción interna entre el absolutismo y la ilustración, crisis que propicia que nuestros protagonistas acepten y a la vez sean víctimas del sistema que defienden.

A pesar de que Estala claramente se autocensura cuando advierte a su amigo que «de noticias políticas nada sé, ni ellas deben jamás tener lugar en nuestras epístolas», con todo, sus cartas no son absolutamente ajenas a lo que está sucediendo y en ellas se alude, siquiera de pasada, a las sangrientas consecuencias del levantamiento revolucionario, a la prohibición de los periódicos y el recrudecimiento de la censura, al soberano poder de la Inquisición y la persecución de los intelectuales, a la caída de Floridablanca y al meteórico ascenso de Godoy, con el pequeño interregno del conde de Aranda, a la guerra contra Francia o a la frustrada conspiración llamada del cerrillo de San Blas, con la que Juan Picornell y otros intentaban desmantelar la monarquía e instaurar un régimen más democrático. Episodios todos ellos de gran relevancia no sólo para la historia del 
país, sino especialmente para las vidas de nuestros protagonistas porque, aunque siempre se les ha reprochado su proximidad al poder, del que está claro que recibieron prebendas y beneficios, no se ha subrayado lo suficiente que, a menudo y por ello mismo, debieron mantener la boca cerrada o se les tapó bruscamente ${ }^{2}$. Y ello porque su ideología oscilaba entre dos posiciones enfrentadas: el rechazo y escándalo que suscita el horror desatado en la nación vecina, que les lleva a aceptar las medidas más reaccionarias para evitar la quiebra de la autoridad del sistema monárquico, y la esencial creencia en los fundamentos de la revolución, que no son otros que los de la Enciclopedia: igualdad, fraternidad, tolerancia, humanidad, educación. Estala, Moratín, Meléndez, Jovellanos, Melón (incluso el reaccionario Forner) constituyeron por tanto, una élite intelectual ilustrada y regalista, de carácter moderado y conciliador, equidistante entre el radicalismo democrático de los que no se conformaban con las tímidas reformas iniciadas por Carlos III (como Picornell o Marchena), y la involución conservadora, absolutista y católica propugnada por gran parte de la iglesia y la nobleza privilegiada.

\section{Esta edición}

Como ha investigado el profesor François López, «la mayoría de las cartas escritas por Forner o a él dirigidas por su amigos, protectores y conocidos ha desaparecido ${ }^{3} »$. Las que se conservaban fueron reunidas por Luis Villanueva, que se las dejó a L. A. Cueto para su trabajo sobre la poesía del siglo XviII; por él sabemos que había cartas autógrafas de Iglesias, Estala, Florián, Trigueros, Quintana, Arjona, Arroyal, Navarrete, Campomanes, Llaguno, Moratín, Marchena y otros ${ }^{4}$. El epistolario volvió a manos de Villanueva, que se lo regaló a

2 No deja de ser paradójico que para acallar los afanes reformistas de los ilustrados, el gobierno situara a las mejores personalidades en puestos de relevancia desde los que, no sólo no van a poder hacer ningún cambio, sino desde los que finalmente serán vigilados, destituidos, trasladados o encarcelados de manera forzosa, acusados de ser jansenistas y antirreligiosos. Basta con no olvidar las ambiguas relaciones de Godoy con los intelectuales; por ejemplo, Forner es nombrado fiscal del Consejo de Castilla, pero no puede publicar sus obras más críticas (las Exequias, sus ensayos sobre la tortura, sobre los toros o sobre la historia); en 1797 Jovellanos es nombrado ministro de Gracia y Justicia y Meléndez fiscal de la Sala de Alcaldes de Casa y Corte, pero el desempeño de tales labores es efímero, pues a finales de año, cuando Godoy es sustituido por el ministro Caballero, son detenidos, confinados, desterrados y acallados sus proyectos de reforma en campos como la economía o la jurisprudencia. Poco después, en 1798, el propio Estala verá descartada su candidatura como bibliotecario primero de los Reales Estudios de San Isidro por la de José Villarroel, capellán de Godoy.

3 Cfr. F. LÓPEz, Juan Pablo Forner (1756-1797) y la crisis de la conciencia española en el siglo XVIII, Salamanca, Junta de Castilla y León, 1999, págs. 605-606.

4 Se trataba de un volumen de Cartas de varios literatos a Forner, según noticia de L. A. DE Cueto, «Bosquejo histórico-crítico de la poesía castellana en el siglo XVIII», en Poetas líricos del siglo XVIII, t. I (BAE, LXI), Madrid, Atlas, 1952, pág. CXv, n. 3. 
Antonio Cánovas del Castillo, tras cuya muerte la colección fue adquirida por Juan Pérez de Guzmán. Será éste quien copie en 1911 la serie de cartas que ahora se reimprime, las únicas que han sido publicadas de manera independiente $^{5}$. Hoy la colección sigue perdida y la infatigable búsqueda del profesor López ha sido infructuosa. La pista se pierde tras la muerte de Pérez de Guzmán, una parte de cuyo legado pasa al marqués de Lede y otra a la Hispanic Society de Nueva York, pero en ninguno de los dos archivos han podido ser encontradas; así mismo, los herederos de Cánovas del Castillo se han negado a realizar las pesquisas suficientes para localizar el preciado paquete. De manera que, como señala el profesor López, «por el momento, pues, la recopilación que utilizó en su día Cueto debe considerarse perdida o inaccesible ${ }^{6}$ ».

Por tanto, mi edición se basa en los únicos testimonios que hoy se pueden manejar: la trascripción hecha por Pérez de Guzmán (PG), que he tomado como texto base, y los fragmentos publicados por Cueto $(\mathrm{C})$ en las siguientes páginas de su Bosquejo: pág. CXVII (un fragmento de la carta v); pág. CXVIII (un fragmento de la carta I); págs. CXLIII-CXLIV (un fragmento de la carta XIX) y pág. CCII (un fragmento de la carta XVIII). Las variantes que han resultado del cotejo de ambos testimonios son recogidas a pie de página en notas introducidas con numeración romana.

En esta nueva edición las cartas aparecen también numeradas del 1 al 21, pero ahora han sido ordenadas cronológicamente en la medida en que los datos internos han permitido establecer una datación concreta o aproximada ${ }^{7}$. Así, junto a cada número se añade la fecha conocida o conjeturada de la carta, pero además mantengo entre paréntesis la numeración romana establecida por Pérez de Guzmán, así como las páginas que la carta ocupaba en su trascripción para el Boletín de la Real Academia de la Historia, con el fin de que pueda observarse la arbitrariedad cronológica del benemérito legatario.

Las notas a pie de página son de dos tipos. Hay un grupo bastante considerable en las que he intentado aclarar datos históricos y biográficos que hoy podrían resultar oscuros fuera de su contexto e identificar, si no a todos, al mayor número posible de personajes citados. En cuanto a las notas introducidas con numeración romana sirven, por un lado, como ya he dicho, para recoger las variantes que han resultado del cotejo entre los fragmentos citados por Cueto y las cartas transcritas por Pérez Guzmán, y, por otro, tanto para introducir aclaraciones léxicas y semánticas como para traducir las expresiones en otros idiomas.

5 Cfr. J. Pérez de Guzmán, «Veintiuna cartas inéditas de D. Pedro Estala...», ed. cit.

6 Cfr. López, Juan Pablo Forner, pág. 606.

7 Excepción hecha de cuatro de ellas en las que figura la fecha al final de las mismas; me refiero a las cartas 1, 6, 11 y 13 . 
Por lo demás, modernizo las grafías, desarrollo las abreviaturas (excepto $V m$.) y me atengo a las recomendaciones que establece la Real Academia Española en cuanto a los criterios actuales de puntuación y acentuación.

\section{Cartas de Pedro Estala a Juan Pablo Forner (1789-1795)}

\section{Carta I}

Salamanca, 12 de agosto de 1789 (PG, VII: 14-16)

Te debo dos epístolas: cátate pagado con ésta, que será luenga o corta, según lo que me vaya viniendo a las mientes... La vacante de Muruzábal me tienta muy poco; algo más me mueve la de Ayala, pero no de suerte que esté ya enteramente resuelto a oponerme ${ }^{8}$. Nuestras circunstancias son fatales, nuestros genios los más impropios para adelantar nuestra fortuna. ¿Crees tú que podré yo sacar algún partido en competencia de un don Rosendo ${ }^{9}$, pedante, adulador y mal hombre, por la razón precisa de ser mal escritor? Y ¿qué diablos haré yo en Madrid? Mentiri nescio; librum, si malus est, nequeo laudare ${ }^{10}$. Además, yo tengo algunas noticias del giro que van tomando los pensadores y filosofastros; sé que se murmura mucho del ministerio y de la corte, y que ésta no es sorda ni insensible a las murmuraciones. Cata que mañana no se contenten con maldecir verbalmente y comiencen a esparcir folletos o libelos. Empieza la averiguación: ¿Quién sabe componer mejores sátiras? ¿Quién escribe mejor? N. y N. y N., pues que sin más informes les cojan y vayan a Orán ${ }^{11}$. Y no faltará en tal oca-

${ }^{8}$ Se refiere Estala a la propuesta que Forner parece haberle hecho para que se presente a las oposiciones que se van a celebrar en los Reales Estudios de San Isidro para cubrir las cátedras de Poética y Retórica. La vacante de José Muruzábal, catedrático de Retórica, era poco tentadora porque tenía carácter provisional, dado que se trataba de una baja por enfermedad. En cambio, la cátedra de Poética estaba vacante por la muerte de Ignacio López de Ayala el día 24 de abril de 1789. Cfr. J. Siмón Díaz, Historia del colegio imperial (Del Estudio de la Villa al Instituto de San Isidro: años 1346-1955), Madrid, Instituto de Estudios Madrileños, 1992 (2. ${ }^{\text {a }}$ ed. actualizada), págs. 320, 329 y 331.

9 Personaje del abogado que aparece en El café extranjero, un famoso sainete de Ramón de la Cruz, mediante el que Estala alude, por antonomasia, a alguna persona cuya identidad no he podido averiguar.

10 Juvenal, Sátira 3: «Quid Romae faciam? Mentiri nescio; librum / si malus est, nequeo laudare et poscere...», que puede traducirse: “¿Qué puedo hacer en Roma? No quiero mentir; si un libro es malo, no puedo alabarlo...».

11 Situada al norte de Argelia, era colonia española desde 1509; perdida posteriormente, fue reconquistada en 1732, aunque será cedida a la regencia de Argel en 1791. Allí cumplían condena de destierro los imputados con tal pena; entre estos cabe recordar a Vicente García de la Huerta, que estuvo desterrado en Orán de 1769 a 1777, acusado de escribir una sátira contra el conde de Aranda. 
sión algunos de los pedantes cuyas ridiculeces habremos pintado ${ }^{12}$ que, quizá teniendo parte en los libelos, se valga de esta ocasión para satisfacer a su venganza, apartando juntamente de su cabeza el golpe. Acuérdate de lo que sucedió a los buenos ingenios del siglo pasado ${ }^{13}$. Esta consideración y algunas otras me hacen mirar con la mayor indiferencia mi establecimiento en Madrid. Pero no puedo menos de compadecerme de tu suerte que, alimentado de esperanzas y expuesto por tu genio a los tiros de la envidia, puedes ser algún día la víctima. Si yo me hallara en tu lugar, lo dejaría todo, vendría a tomar la cátedra que deja Meléndez ${ }^{14}$, la cual te daría una subsistencia muy decente, con la gran satisfacción de no deber nada a ningún atavis $^{15}$, ni tener que adular ni visitar antesalas. Ya que no te resuelvas a esto, a lo menos convendrá que afectes ${ }^{\mathrm{I}}$ esta resolución con esos mecenas ${ }^{16}$, para ver si les hace alguna impresión.

12 Entre los personajes públicos que habían sido objeto de burla, cuando no de duro escarnio, por parte del grupo de amigos estaban, entre otros, Francisco Mariano Nifo, Manuel Laviano, Manuel García Asensio, Antonio Valladares y Sotomayor, Vicente García de la Huerta, los hermanos Iriarte, Ignacio López de Ayala o Cándido María Trigueros. La reacción crítica de los jóvenes escritores contra el gusto y estilo de estos autores más o menos consagrados se gesta en los primeros años de la década de los ochenta, como puede verse en el manuscrito Versos y prosas que se han escrito en una cofradía de hombres de letras en celebridad de las Felicidades de España, para exemplo y escarmiento de los que las han celebrado indignamente (Biblioteca Nacional de Madrid, ms. 3703), dentro del cual se incluye un viaje burlesco al monte Parnaso firmado por Damón que puede leerse en M. Arenas Cruz, «Un Viaje al Parnaso de Pedro Estala», Dieciocho, vol. 26, I (Spring, 2003), págs. 131-157.

13 Estala era muy consciente del poder que estaba recuperando la Inquisición, cuya ayuda había sido reclamada por Floridablanca para frenar el influjo en nuestro país de la Revolución francesa. Años después, en El Imparcial, se referirá precisamente a esto que ahora sólo le apunta a su amigo: «En el reinado de Felipe II florecieron españoles eminentes en todos los ramos del saber: los escritores superficiales o preocupados atribuyen esta gloria a aquel rey, pero es tan al contrario, que ningún otro soberano ha trabajado con más ardor ni con mejor suceso en destruir los buenos estudios. Estimuló la Inquisición para que persiguiese a todos los hombres grandes: fray Luis de León gimió por algunos años en sus calabozos; otros muchos huyeron a países extranjeros; los demás escarmentaron con tan terribles ejemplos y se condenaron al silencio». Cfr. P. EsTALA, «Instrucción pública», El Imparcial o Gaceta Política y Literaria (marzo-agosto, 1809), pág. 62.

14 Juan Meléndez Valdés (1754-1817) era catedrático titular de Prima de Letras Humanas en la Universidad de Salamanca desde 1781. Tras numerosas gestiones y gracias al apoyo de Jovellanos y de Campomanes (a la sazón gobernador interino del Consejo de Castilla), es nombrado juez criminal en el Real Tribunal de Aragón, cargo que jura en mayo de 1789. Cfr. A. Astorgano Abajo, Don Juan Meléndez Valdés. El Ilustrado, Badajoz, Diputación Provincial, 2007, págs. 285-288.

15 Repárese en la sutil metonimia que Estala introduce en esta frase a partir del Carmen I, 1, 1 de Horacio, que comienza «Maecenas, atavis edite regibus»(Oh, Mecenas, nacido de antepasados regios), que le lleva a conferir, por proximidad, al sustantivo atavis, «antepasados», el significado de «mecenas», «persona que patrocina las artes y las letras» (conocida antonomasia por alusión a Cayo Cilnio Maecenas, amigo del emperador Augusto y protector de los literatos). Es probable que fuera un guiño compartido por los amigos, pues también lo encontramos en Moratín, que en una carta dirigida a Melón el 18 de enero de 1795 escribe, refiriéndose a Godoy: «No he recibido carta alguna de Bernabéu; dile, o escríbele, que envié las Pascuas en verso al atavis». Cfr. L. F. DE Moratín, Epistolario, ed. de R. Andioc, Madrid, Castalia, 1973, carta 185.

I Afectar, en sentido latino, affectare, «procurar alguna cosa con ansia o ahínco» (DRAE).

16 El principal mecenas y valedor de Forner era don Eugenio Llaguno (1724-1799), alto funcionario de la Secretaría de Estado y miembro de la Academia de la Historia, gracias a cuyo concurso el conde de 
¡Dichoso Arcadio!17 Él goza de una renta más que suficiente; filosofa y poetiza a su sabor, sin zozobra ni cuidado; goza del incomparable placer de hacer bien a los que lo merecen, que son los pueblos infelices que están a su cuidado. Su casa es el refugio de todos los pobres; con ellos reparte su renta, les da consejos y documentos ${ }^{\mathrm{II}}$ admirables para disminuir sus trabajos y miserias; compone todos los pleitos o, cuando son indispensables, toma a su cargo la defensa de la inocencia y de la justicia oprimida y disipa los errores y preocupaciones perjudiciales, para que su sencilla credulidad no sea tributaria de la hipocresía y superstición. He aquí la verdadera filosofía: él no dogmatiza ni sentencia como nosotros, varones doctísimos, pero sabe gozar de la vida y estar contento con su suerte. Te aseguro que a pesar de la corrupción de mi ánimo, efecto del trato cortesano y de la lectura, envidio su suerte, y quizaces, quizaces, la tomaría para vivir perpetuamente oblitusque meorum, obliviscendus et illis ${ }^{18}$.

Batilo está disponiendo su marcha ${ }^{19}$; quiere que hagamos primero un viaje a las Batuecas, do diz que tiene hecha una singular promesa. Iremos, porque creo ha de ser la romería un poco poética ${ }^{20}$. Está recogiendo sus escrinios ${ }^{\mathrm{III}}$ para

Floridablanca acelera los trámites de censura y financia algunas obras del extremeño, entre ellas la Oración apologética por la España y su mérito literario (Madrid, Imprenta Real, 1786) y los Discursos filosóficos sobre el hombre (Madrid, Imprenta Real, 1787). Una semblanza de este personaje se puede ver en J. AprÁIz, «El ilustre alavés don Eugenio de Llaguno y Amírola», Boletín de la Real Sociedad Vascongada de Amigos del País, I (1948), págs. 53-95. Otros valedores de Forner fueron Miguel María de Nava, consejero de Estado, Francisco Pérez de Lema o el propio Campomanes.

17 Se trata de José Iglesias de la Casa (1748-1791), a quien Estala conoció en Salamanca en torno a 1776. Ordenado presbítero en 1783, se dedicaba a cumplir su misión de párroco en diferentes pueblos de esta provincia. Morirá con cuarenta y tres años de edad el 26 de agosto de 1791.

II Documento, en sentido latino «instrucción que se da a alguien en cualquier materia y particularmente, aviso y consejo para apartarle de obrar mal» (DRAE).

18 La cita procede de Horacio, Epístola I, 11, vv. 8-10, y puede traducirse «olvidado de los míos para que también ellos me olviden». Cfr. Horacio, Sátiras. Epístolas. Arte Poética, ed. de Horacio Silvestre, Madrid, Cátedra, 1996, pág. 411.

19 Batilo es el nombre pastoril de Juan Meléndez Valdés, quien, después de pasar casi todo el primer semestre en Madrid haciendo las gestiones oportunas para conseguir un puesto más remunerado, en junio regresa a Salamanca a hacer los preparativos para su marcha a Zaragoza. Pasa un ajetreado verano, en el que asiste a todos los claustros de la Universidad, hasta que toma posesión de su nuevo puesto el día 15 de septiembre de ese año. Cfr. Astorgano Abajo, Don Juan Meléndez Valdés, págs. 285-288.

20 Según Demerson, los amigos realizarían este viaje de índole más o menos religiosa, quizá al santuario de Nuestra Señora de la Peña de Francia o algún otro de la zona, entre el 13 y el 21 de agosto de 1789, pues el día 22 Meléndez participa en un claustro de la Universidad. Cfr. G. Demerson, Don Juan Meléndez Valdés y su tiempo (1754-1817), Madrid, Taurus, 1971, págs. 253-254.

III Escrinios, del latín scrinium, «cofrecillo, estuche para guardar papeles». Conjeturo que el neologismo nace de la combinación de la metonimia (el continente por el contenido) con la paronimia (escrinios = escritos). 
dejarlos en poder de Jovino para la impresión ${ }^{21}$. ¡Y ese mezquino de Mirtilo $^{22}$ anda en esos malos pasos! Siempre lo dije yo, que no habrá vileza a que no se abata. Ya le escribiré un poco de parenética ${ }^{\mathrm{IV}}$. Yo ya no voy estas vacaciones a Madrid: motivos muy justos me detienen aquí. No sé si iré después que se haga la traslación del cuerpo del inquisidor ${ }^{23}$ o si lo dejaré para otro año. Si tuviese yo aquí una Flérid ${ }^{24}$ o cosa equivalente, y un par de vosotros, adiós corte para siempre.

Nada me has escrito del gran proyecto del diario poético de Burguillos: ¡qué pérdida tan lastimosa para el Parnaso del Rastro ${ }^{25}$ que no se verifique! ${ }^{26}$ Dime

$21 \quad$ Jovino es Melchor Gaspar de Jovellanos (1744-1811), con quien Meléndez mantuvo una profunda y duradera amistad. Siempre lo consideró su consejero literario e intelectual, así como su protector y guía en el ámbito profesional. Cfr. Astorgano Abajo, Don Juan Meléndez Valdés, págs. 313-324.

22 Pérez de Guzmán adjudica en nota este seudónimo a Martín Fernández de Navarrete (PG, 15). Sin embargo, como apunta Juan Antonio Melón, Mirtilo «fue el nombre que tuvo don Leandro hasta que le hicieron árcade» (cfr. J. A. MELón, «Desordenadas y mal digeridas apuntaciones», Biblioteca Nacional, ms. 18.666,f. 3r), es decir, hasta febrero de 1794, fecha en que ingresa en la Academia de los Árcades de Roma. A partir de entonces siempre firma como Inarco Celenio, $P$. A. (poeta árcade). Véase, por ejemplo, L. FERnándEZ De Moratín, Epistolario, carta 45.

IV Parenética, relativo a la parénesis, esto es, exhortación o amonestación (DRAE).

23 Se trata de Felipe Bertrán, obispo de Salamanca e inquisidor general, muerto en Madrid en 1783, pero cuyos restos iban a ser ahora trasladados a la ciudad del Tormes, a donde llegan el 13 de octubre de 1789. Estala había colaborado estrechamente con él durante los años en que estuvo negociando para conseguir fundar, en 1779, el Real Seminario Conciliar de San Carlos en Salamanca. En las solemnes ceremonias que se le van a tributar, nuestro helenista pronuncia una Oración fúnebre latina, en la que se trasluce su afecto y cercanía; será traducida e impresa al año siguiente: Solemnes exequias en la santa iglesia de Salamanca y real seminario de San Carlos en la traslación del cadáver del excelentísimo señor don Felipe Bertrán, obispo de Salamanca, inquisidor general, Madrid, Antonio de Sancha [1790].

24 Es el nombre supuesto de la enamorada y musa de Forner en Madrid, a la que dedica sus composiciones amorosas antes de casarse. También Moratín tiene un soneto «A Flérida, poetisa», que, según conjetura de René Andioc, acaso fuera la misma persona. El erudito francés apunta la posibilidad de que se trate de una hermana de Joaquín Cros, a quien Moratín escribe desde París el 2 de julio de 1787. Cfr. L. F. DE Moratín, Epistolario, pág. 88, n. 2.

25 Tomé de Burguillos es un álter ego de Lope de Vega, bajo cuyo nombre publica una colección de poesías fingiendo su existencia real. Aunque la crítica más solvente ha demostrado que Burguillos es un heterónimo de Lope, Estala y otros autores tomaron como ciertas las palabras del prólogo, donde Lope afirma que conoció en Salamanca a este poeta, que le dejó La gatomaquia y otros poemas antes de marcharse a Italia. La primera parte de las Rimas humanas y divinas del licenciado Tomé de Burguillos (Madrid, 1634) es una colección de sonetos a modo de canzoniere dedicado a una tal Juana, lavandera del Manzanares, en los que, con gran humor y desenfado, Lope desmonta toda la imaginería petrarquesca. Cfr. F. B. PEdRAZA y M. Rodríguez Cáceres, Manual de Literatura III. Barroco. Introducción, prosa y poesías, Pamplona, Cenlit, 1980, págs. 585-589. Burguillos no pertenece, por tanto, al Parnaso de Apolo, sino al del Rastro, barrio de Madrid situado en las cercanías del río Manzanares.

26 De sus palabras puede deducirse que Estala sospechaba que este trabajo no iba a ver la luz, pues en estas fechas ya no existe la compañía que tenía formada con el cirujano Ramón Fernández para editar una colección de poetas castellanos. Financiadas por éste, ya habían sido publicadas, entre 1786 y 1789 , las ediciones que Estala había preparado de las poesías de Francisco de Figueroa, los hermanos Argensola, Fernando de Herrera, Juan de Jáuregui y Luis de Góngora, precedidas, excepto la primera, de sustanciosos prólogos. No obstante las previsiones de Estala, las Rimas de Tomé de Burguillos aparecerán en el tomo XI 
en qué ha parado la suscripción de $\operatorname{Longo}^{27}$, al cual encargarás que disponga cómo se ha de pagar a Barco $^{28}$ el importe de los carteles que mandó tirar.

Mi dulce remembranza a la divina Flérida, contra la cual tengo la más justa queja por no haberse dignado de ponerme siquiera una posdata.

Salamanca, 12 de agosto de 1789.

Damón $^{29}$

\section{Carta II}

Salamanca, primeros meses de 1790 (PG, II: 8)

Que tú eres un tigre es una verdad demostrada. Bravo chasco me llevara ${ }^{\mathrm{V}}$ yo si no te conociese intus et a inter $^{\mathrm{VI}}$. Dime, maldito de Dios y de todos sus santos, en qué piensas que aún no me has escrito si has recibido los 700 ejemplares. Y, ¿por qué no debías avisarme del efecto que ha producido en los reos y de la impresión que ha hecho en el público ${ }^{30}$ ? ¿Así te comportas con tus amigos,

de la Colección (Madrid, Imprenta Real, 1792), aunque sin prólogo crítico. Para la identidad de Ramón Fernández y sus relaciones con Estala, véase R. ANDioc, «Ramón Fernández siempre será Ramón Fernández», Ínsula, 504 (1988), págs. 18-19. Sobre los avatares de esta colección de poesía puede consultarse J. CHECA Beltrán, «El libro: la Colección de poetas castellanos (1786-1798)», en J. Álvarez Barrientos (ed.), Espacios de la comunicación literaria, Madrid, CSIc, 2002, págs. 107-128; y mi trabajo, Pedro Estala, vida y obra (Una aportación a la teoría literaria del siglo XVIII español), Madrid, CSIC, 2003, págs. 158-191. Los prólogos que encabezaban cada volumen han sido editados por mí: P. EsTala, Prefacios y artículos de crítica literaria, Ciudad Real, Diputación Provincial, 2006.

27 Deduzco que se trata del murciano Diego Antonio Rejón de Silva (1754-1796), pintor y académico, entre cuyas obras cabe citar el poema didáctico «La pintura» (1786). Era hijo de Diego Ventura Rejón de Silva y Lucas, el verdadero autor de la novela Aventuras de Juan Luis. Historia divertida que puede ser útil (1781), a quien Forner llama Macro-Longo en la segunda parte de su romance contra García de la Huerta, según lo identificó Cueto en su antología de Poetas líricos del siglo XVIII, BAE, LXIII, pág. 335, n. 9. Este dato ha sido confirmado por R. ANDIoc en «Una fazaña más de García de la Huerta», en Del siglo XVIII al XIX. Estudios histórico-literarios, Zaragoza, PUZ, 2005, pág. 335, n. 94. Sobre Longo puede consultarse el trabajo de C. Peña Velasco, Aspectos biográficos y literarios de Diego Antonio Rejón de Silva, Murcia, Consejería de Cultura y Educación, 1985.

28 Juan Barco era un librero salmantino que poseía un establecimiento en la plaza de la Universidad y hacía negocios con ésta. En 1793 se ocupará de la venta del Semanario erudito y curioso. Cfr. G. Demerson, Meléndez Valdés y su tiempo, I, pág. 100. Según aparece en algunos anuncios del Diario de Madrid, Barco tenía otra librería en la carrera de San Gerónimo en Madrid. Véase, por ejemplo, el núm. 45, del lunes 15 de febrero de 1796, pág. 183.

29 Nombre pastoril que aparece en las Bucólicas de Virgilio, en concreto en la III y en la VIII. Fue adoptado por Estala en sus años juveniles, a imitación de sus amigos poetas: Forner firmaba Amintas; Meléndez Valdés, Batilo; José Navarrete, Alfesibeo; José Iglesias, Arcadio; y Moratín, Mirtilo.

$\checkmark \quad$ llevara [corrección mía] llevaba PG, 8.

VI Intus et a inter es una expresión imposible, que podría traducirse «por dentro y entre dentro».

30 Para entender el contenido de esta carta hay que remontarse a 1784, cuando Cándido María Trigueros (1736-1798) publicó su extenso poema didáctico «La riada», duramente criticado por Forner en su Carta de don Antonio Varas al autor de La riada, sobre la composición de este poema (Madrid, Miguel Escribano, 
demonio? ¿Es ésta tu filosofía, camello? Pues mira, voy a escribir a los Guarinos y Trigueros demandándoles admitan mis humildes ${ }^{\mathrm{VII}}$ excusas y sensibles regretes ${ }^{\mathrm{VIII}}$ de haber cooperado a esta maniobra, y al mismo tiempo dándoles cuenta

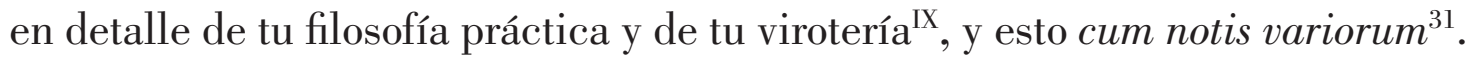
Ese camello de Pascual es otro que tal ${ }^{32}$ : me hizo tirar aquí carteles de reclamo para su obra y ni he visto un maravedí33, ni ha enviado al librero el segundo ejemplar. Dios os confunda.

Salamanca, a qué sé yo cuántos.

Damón $^{34}$

1784), edición requisada en su totalidad por el Consejo de Castilla, que además prohibió a Forner volver a publicar libelos anónimos. Años más tarde, Juan Sempere y Guarinos dedica a su amigo Trigueros cincuenta elogiosas páginas en su Ensayo de una biblioteca de los mejores escritores del reinado de Carlos III (1789), mientras que Forner sólo merecerá diez. El carácter poco templado del extremeño no pudo soportar la comparación ni alguna que otra alusión desagradable en su contra y escribió un Suplemento al artículo Trigueros, comprehendido en el tomo 6 del Ensayo de una biblioteca..., que será publicado anónimamente en Salamanca (Francisco de Tójar, 1790) a instancias de Estala. En la presente carta el helenista se queja de que Forner no le haya contestado tras recibir los ejemplares impresos de este libelo.

VII humildes [corrección mía] hunibles PG, 8.

VIII Adaptación castellana del francés sensibles regrettes, con el significado de «sentido disgusto o pesar».

IX Neologismo formado a partir de virote, «hombre erguido y demasiadamente serio y quijote» (DRAE). Dice Covarrubias: «Traga virotes llamamos a los hombres muy derechos y muy severos, con una gravedad necia que no les compete a su calidad» (Tesoro).

31 Referencia burlona a una expresión propia de la jerga erudita: una editio cum notis variorum editorum es aquella en la que se incluyen no sólo las notas del editor que ha establecido el texto, sino también las de los críticos anteriores.

32 Creo que se trata de Pascual Arbuxech, el compañero de cuarto de Forner, según éste dice en la declaración que hizo ante el juez Flores en el pleito de Estala con Ramón Fernández a propósito de la traducción de las Reflexiones sobre el origen de los descubrimientos atribuidos a los modernos. En ella menciona que Estala y el librero Gómez fueron a su casa, «donde en presencia y con intervención de D. Pascual Arbuxech, mi compañero de cuarto, se trató el negocio y no se efectuó». Cfr. R. ANDioc, «Ramón Fernández siempre será Ramón Fernández», págs. 18-19. Arbuxech era doctor en teología y abogado. Es probable que la obra a la que Estala se refiere sea El hombre de Estado. Obra escrita en italiano por Nicolás Donato, traducida al francés y comentada con un gran número de notas, sacadas de los autores más célebres que han escrito sobre materias políticas, y de éste al castellano, Madrid, Benito Cano, 1789, en dos tomos, el segundo de los cuales, impreso en la Imprenta Real en 1790, es quizás el que todavía no ha recibido el librero.

33 El maravedí fue una moneda española que circuló en la Edad Media con diferentes valores y calificativos. Conjeturo que aquí aparece como sinónimo de dinero, pues el maravedí es una unidad de cuenta, es decir, que no tiene por qué existir físicamente, y, según las épocas, puede utilizarse sólo conceptualmente, esto es, para facilitar las equivalencias entre monedas. Por tanto, se puede decir que un real equivale a un número determinado de maravedíes, pero nadie puede comprar con maravedíes, porque físicamente no existen y debería pagar en monedas de real. Debo esta información al historiador Roberto Mendès Barbudo.

34 Pérez de Guzmán incluye a continuación lo anotado en el sobreescrito: «Calle del Mesón de Paredes, esquina a la de las Dos Hermanas, cuarto bajo. Madrid». Esta era, por tanto, la dirección de Forner en la capital en estas fechas. 


\section{Carta III}

Salamanca, anterior a julio de $1790^{35}$ (PG, XII: 20-21)

No podíamos desear mejor éxito de nuestro asunto, y hablo de veras. Con la prohibición es preciso que haya recibido un nuevo realce la $\cos a^{36}$. Yo, por lo menos, me ando gloriando por aquí de la tal defensa. Aun los mismos ejecutores han conocido la sinrazón, y el modo con que han procedido ahí y aquí muestra que están bien convencidos de la injusticia. Me han asegurado aquí que Iriarte ha sido el que más ha intrigado ${ }^{37}$. Este parece que les inspiró a los otros que el papel se había impreso en Madrid de contrabando, y que era supuesto el nombre del impresor. ¡Mira cuán útil es ser inteligente en la tipográfica! ¡Qué ufanos estarían en el triunfo imaginado! Pero les salió huero. Enviaron orden a este intendente para que informase súbito. El informe fue encajarles en cuerpo y alma mi memorial, en que yo solicitaba la licencia, sin decir más que deseaba imprimir aquel papel, sin insinuar siquiera si era mío ni tuyo ni del gran turco. Juntamente con el susodicho memorial envió la censura del P. M. Díaz ${ }^{38}$ y, en vista de ella, su licencia. ¡Qué estupefactos quedarían! Al correo siguiente de

35 Estala apunta en esta carta que los libelos de Forner le van a impedir alcanzar una «golilla», por tanto es anterior al 20 de julio de 1790, fecha en que el extremeño es nombrado fiscal segundo de la Audiencia de Sevilla, a donde se trasladará al mes siguiente. Cfr. LópEz, Juan Pablo Forner, pág. 500. Estala todavía está en Salamanca, pero será por poco tiempo porque en agosto de este año dejará su puesto de profesor de retórica y griego en el seminario conciliar de San Carlos. Cfr. Libro de los salarios que paga el seminario conciliar de la ciudad y obispado de Salamanca desde el día 21 del mes de septiembre del año, f. 106r (Archivo del Seminario, Universidad Pontificia de Salamanca).

36 El Consejo de Castilla había ordenado requisar los ejemplares que existieran del Suplemento al artículo Trigueros, una medida policial justificada si se piensa que Forner ha incumplido la orden de 1784 por la que se le prohibía publicar libelos anónimos. Según lo que aquí cuenta Estala, los ejecutores de la orden de embargo no se la toman muy en serio: cuando el Consejo pide al intendente de Salamanca que informe sobre la impresión del Suplemento, éste les remite tres documentos: la solicitud de impresión que había presentado Estala, la pertinente censura de P. M. Díaz y, a la vista de ella, la licencia concedida; pero cuando recibe la orden de requisar los ejemplares, éstos ya están en Madrid, en poder de Forner, sin que el intendente se preocupe, al parecer, de interrogar a Estala o al impresor Tójar, responsables en definitiva de que el libelo haya visto la luz. Cfr. López, Juan Pablo Forner, págs. 460-462.

37 Que Tomás Iriarte (1750-1791) fuera de los que más intrigaran para que se confiscara el escrito de Forner no puede causar sorpresa; ya había hecho valer sus influencias con los altos funcionarios del Estado para evitar que se imprimiera la despiadada sátira de Los gramáticos y para conseguir que el fiscal requisara todas las copias manuscritas que Forner o sus allegados poseyeran. Sobre las vicisitudes de la prohibición de esta obra, véase López, Juan Pablo Forner, pág. 277 y ss., así como la edición de John H. R. Polt, Los gramáticos. Historia chinesca, Madrid, Castalia, 1970.

38 No sé quién es este personaje, aunque conjeturo que si consideramos la posibilidad de que Pérez de Guzmán leyera Díaz donde Estala habría escrito Díez, podría tratarse del padre Manuel Díez, un franciscano de quien se conservan unas Cartas a Campomanes sobre la impresión de una gramática griega, filosofía, retórica y matemática para niños, 1773-1774 (Biblioteca de la Fundación Universitaria Española, Papeles de Campomanes, 48-35). Cfr. F. Aguilar Piñal, Bibliografía de autores españoles del siglo XVIII, Madrid, CSIC, 1981-1999, t. III. 
tu aviso tuvo el intendente la orden de recoger los ejemplares que aquí hubiese, pero la orden venía tan fría que no hizo más que estar conmigo amistosamente sin cosa que oliese a declaración, porque en la orden no se hablaba de tal cosa. Remitíle al impresor (aunque no era necesario, ni el intendente lo pedía), para que constase jurídicamente que aquí no quedó ningún ejemplar. Nada se ha tratado de a quién los envié.

Lo que me dices del recurso ${ }^{39}$ me parece muy arriesgado y enteramente superfluo $^{\mathrm{X}}$. ¿Qué mayor venganza quieres que la que ellos mismos nos han dado? Siento infinito que te prostituyas en defensor de esas brutalidades. ¡Si con ellas consiguieses una buena golilla ${ }^{\mathrm{XI}}$ o renta, pase, pero desacreditarse tan vergonzosamente en el concepto de los que no te conocen (que son casi todos) por lisonjear a los que así te tratan, me parece muy mal pensado!

Ya se acabó de imprimir el primer tomo del poema de la Teología ${ }^{40}$. El buen Arcadio habrá perdido su tiempo y, lo que es peor, perderá su dinero. Leíle tu párrafo, ca ${ }^{\mathrm{XII}}$ es muy sano consejo el que le das; yo no sé si lo tomará. Adiós ${ }^{\mathrm{XIII}}$.

Pedro de Estala

\section{Carta IV}

Madrid, enero o febrero de 1791 (PG, XVI: 26-27)

¡Hola! ¿Conque no tengo razón en estar quejoso de ti? ¿Conque son quisquillas y fatuidades de corte el resentirse un hombre de bien de no hallar correspondencia en un amigo? ¿Conque debería yo mirar con indiferencia que un sinnúmero de pícaros me estuviesen dando en las barbas todos los días con cartas tuyas sin ser una para mí por un ojo de la cara? Dígote que, si así lo piensas, eres un menguado, digno sólo de tratar con procuradores, escribanos y canalla de la chicana ${ }^{\mathrm{XIV}}$.

39 Probablemente Forner estaba pensando en solicitar un recurso de amparo ante el Consejo contra la orden de retirar los ejemplares del Suplemento; Estala intenta disuadirlo, pues no entiende que su amigo gaste su talento y su energía en estériles polémicas.

x superfluo [corrección mía] superfluos $\mathrm{PG}, 21$.

XI Golilla, «adorno hecho de cartón forrado de tafetán u otra tela negra, que circundaba el cuello, y sobre el cual se ponía una valona de gasa u otra tela blanca engomada o almidonada; lo usaban los ministros togados y demás curiales» (DRAE).

40 El extenso poema didáctico de José Iglesias de la Casa titulado «La teología» fue publicado en Salamanca por su cuñado, el librero Francisco de Tójar, en 1790.

XII ca, del latín quia, conjunción causal antigua que significa «porque» (DRAE).

XIII Adiós [en todas las ocasiones modernizo la forma A Dios que reproduce PG].

XIV Chicana, del francés chicane, «artimaña, procedimiento de mala fe, especialmente el utilizado en un pleito por alguna de las partes» (DRAE). Estala interpreta gens de chicane, gente de curia, como «canalla de la chicana». 
Pues, sí señor; he estado muy enfadado y lo estoy y lo estaré, hasta que te dé cuatro cachetes, que estas cosas no se componen con palabritas blandas, ni con hacer cuatro pucheritos. Yo traslado a la amistad toda la delicadeza que otros tienen con el amor mujeril; tengo mis celos, mis sospechas, mis caprichos y, por consiguiente, he dicho de ti mil perrerías y aquello de no me hable Vm. de ese hombre, picarón y fementido y demás elogios. Pero de esto ya hablaremos despacio; vamos a tus encargos.

Te remito este correo la Celestina, la cual había ya entregado a Quiroga ${ }^{41}$ para que te la enviase. No me había dado prisa a entregarla porque ignoraba el motivo que tenías para pedirla con tantas instancias. Apruebo tu pensamiento sobre este particular, y estando concluido, envíalo, que se hará la cosa como il faut $^{\mathrm{XV}}$.

Sobre las respuestas a Sánchez, te digo que sería mejor dejarlo, porque ya nadie se acuerda de su folleto ${ }^{42}$. El Frío me dijo días pasados que no te ${ }^{\mathrm{XVI}}$ era decente andar en estas contestaciones y que te lo escribiese así de su parte. Pero si absolutamente quieres que se imprima, envía esos mamotretos, que se copiarán y se harán las diligencias para su impresión. Bernabéu ${ }^{43}$ me dijo que no te escribiría hasta evacuar ${ }^{\mathrm{XVII}}$ un encargo que le habías hecho; en esta inteligencia puedes enviar también esos otros papelajos y se hará todo lo que quieras.

Yo me hallo en el estado más brutal que puedes imaginarte: ni escribo, ni leo, ni pienso. Me es imposible vivir sin amigos y todos se me van marchando: fuese Aminta a Sevilla y Mirtilo a la Alcarria ${ }^{44}$ y yo, povero diablo ${ }^{\mathrm{XVIII}}$, no sé

41 Probablemente se trate de Manuel Losada y Quiroga, un librero e impresor que, según Andioc, hacía ediciones populares en papel de pésima calidad y desprovistas de encuadernación. Moratín alude a él en varias ocasiones. Por ejemplo, véase Fernández de Moratín, Epistolario, carta 52, pág. 183.

XV Adaptación de la expresión comme il faut, «como corresponda».

42 Forner pretende imprimir, a instancias de Estala, otro libelo, esta vez contra don Tomás Antonio Sánchez (1723-1803), el primer editor del Cantar de Mío Cid. El erudito había aludido incidentalmente a Forner en su famosa Carta de Paracuellos (Madrid, Viuda de Ibarra, 1789) citándolo entre otros escritores objeto de su sátira. Este hecho bastó para que el extremeño se indignase y le contestase en su Carta de Bartolo, el sobrino de don Fernando Pérez, tercianario de Paracuellos, al editor de la carta de su tío. Publícala el licenciado Paulo Ipnocausto (Madrid, Imprenta Real, 1790); en ella trata a Sánchez como «a un anticuado en materias críticas, colector de obras ajenas, sin literatura ni criterio». Don Tomás replicó entonces con un folleto titulado Defensa de D. Fernando Pérez, autor de la carta de Paracuellos, impugnada por el licenciado Paulo Ipnocausto. Escribíala un amigo de D. Fernando (Madrid, Viuda de Ibarra, 1790). Por la presente carta sabemos que Forner tenía intención de volver a contestar a don Tomás.

XVI te [corrección mía] le PG, 26.

43 Francisco Bernabéu era un guardia de Corps de la Compañía Italiana de San Ildefonso. Amigo de Forner, Moratín y Estala, es quien les presenta a D. Luis Godoy, a través del cual conocerán a su poderoso hermano Manuel, del que obtendrán beneficios y ventajas.

XVII Evacuar, en el lenguaje del derecho, «cumplir un trámite, un encargo o diligencia» (DRAE).

44 Moratín viajaba mucho a Pastrana, donde tenía familia y donde terminará por comprar una casa.

XVIII Povero diablo, pobre diablo, «hombre bonachón y de poca valía» (DRAE). 
dónde me vaya. Sabe que se han publicado los edictos para la cátedra de Poética, que he firmado para la oposición y que después de quince días mi firma es la primera y la última. Mucho hablar de mí, mucho preguntar si sé, si no sé, si soy el diablo, etc. En suma, haré la oposición, me futraré $\mathrm{XIX}$ en tirios y troyanos, no me la darán y en tal caso, quid faciendum ${ }^{\mathrm{xx}}$ ? Cogeré un bordón de peregri$\mathrm{no}^{\mathrm{XXI}}$ y piano piano ${ }^{\mathrm{XXII}}$ me iré por esos mundos adelante y Cristo con todos ${ }^{\mathrm{XXII}}$.

Vaya, vaya, que esta epístola ya va siendo larga para lo que mereces. Azota, ahorca, empapela ${ }^{\mathrm{XXIV}}$ a todo pobre diablo que caiga en tus manos, que yo para ahorcarme no necesito de informe fiscal. Agur ${ }^{\mathrm{Xxv}}$.

\section{Pedro de Estala}

\section{Carta V}

Madrid, abril de 1791 (PG, XV: 24-25)

Si tú estás fastidiado de tu empleo, yo lo estoy de la vida. Yo ${ }^{\mathrm{XXV}}$ estoy sano, gordo, nada me falta para una decente subsistencia, pero ¿̇de qué sirve esto ${ }^{\mathrm{XXVII}}$ si falta el placer que hace apetecible la vida? Voy arrastrando una fastidiosa existencia, en que no hallo más que una monotonía maquinal de operaciones periódicas. Si me pongo a pensar, el pensamiento es mi verdugo. Me representa el estado miserable en que me hallo, solo, aislado, sin un amigo, y esto me basta para ser infeliz. Cuando quiero huir de estas dolorosas consideraciones con la disipación, en medio de tales diversiones me asalta la maldita reflección ${ }^{\mathrm{XXVIII}}$ y me hace amargos los mayores placeres. No tengo ${ }^{\mathrm{XIX}}$ gusto para leer, mucho menos para escribir; tiro a pasar los días lo más inútilmente que puedo ${ }^{\mathrm{Xx}}$. Como

XIX Futraré, palabra inexistente en castellano; se trata de un neologismo a partir del verbo francés foutre, «joder». Leandro Moratín lo usa para titular su poesía erótica: Fábulas futrosóficas o La filosofía de Venus en fábulas (Londres, 1822).

xx Quid faciendum?, « ¿qué hay que hacer?».

xXI Bordón, «bastón o palo más alto que la estatura de un hombre, con una punta de hierro y en el medio de la cabeza unos botones que lo adornan» (DRAE).

XXII Piano, piano, en italiano «despacio, despacio».

xXIII Cristo con todos, «salutación equivalente a la latina Pax Christi y que solía utilizarse al fin de las cédulas de cambio». Se puede considerar una «expresión familiar con que se da fin a un asunto o altercado» (DRAE).

XXIV Empapelar, figurada y familiarmente «formar causa criminal a uno, abrir expediente a alguien» (DRAE).

XXv Agur, del latín augurium, a través del vasco agur, interjección que se usa para despedirse (DRAE).

XXVI Yo PG, 24. Omitido en C.

XXVII esto PG, 24; la vida MP, 559.

xxVIII reflección $\mathrm{PG}, 24$; reflexión $\mathrm{C}$. Es una dolencia parecida a un calambre: un miembro se retrae, se vuelve hacia atrás.

XXIX No tengo $\mathrm{PG}, 24 ;$ Ni aun tengo $\mathrm{C}$.

xxx puedo[corrección mía] pueda PG, 24. 
no tengo objeto a quien dirigir mis versos, ni Amintas o Mirtilas a quien leerlos, no me acuerdo de que hay musas en el mundo, sino para llorar aquella dulce época en que vivíamos felices con nuestros delirios. Ma paso quel tempo, Enea ${ }^{45}$. Cuando tiendo la vista por lo futuro, no veo más que una serie de tristezas, molestias y dolores. La única esperanza que me hace aguantar la vida es la de que algún día puede ser que nos juntemos.

Éste es el resultado de lo que veo, oigo y sufro. Tú puedes suponer qué tal será ello cuando me infunde tan profundo chagrin $^{\mathrm{XXXI}}$. Deseando estoy que se acabe esta oposición, pues inmediatamente cojo un bordón y pitagóricamente me voy por esos mundos adelante. Si en el camino me llega la noticia de que me han dado la cátedra (cosa que no creo), volveré; pero si no, jadiós corte para siempre! Tú, en todo caso, ya puedes ir disponiéndome habitación en alguna guardillaxxXII, y buscándome lecciones que leer, escribir o copiar papeles, o cosa tal, porque el día menos pensado me hallarás a tu puerta con mi bordoncito y esclavina ${ }^{\text {XXXII }}$. Haré primero un ensayo de mis fuerzas para viajar haciendo una visita a Mirtilo en la Alcarria; y si, como espero, mis gambas $^{\mathrm{XXXIV}}$ sufren la peregrinación, Sevilla me verá trotar sus calles antes del invierno.

Desde que no hay periódicos, estamos aquí sepultados en tinieblas palpables de ignorancia. Los sabios que tenían hecho el asiento de nuestra instrucción han insistido por que se les permita continuar; pero su majestad, atendiendo sin duda a que sujetos tan beneméritos deben descansar para que la patria no se quede sin ellos al mejor tiempo, ha tenido por conveniente continuarles las vacaciones para siempre jamás, amén ${ }^{46}$.

De noticias políticas nada sé, ni ellas deben jamás tener lugar en nuestras epístolas. Sólo te participaré la muerte del buen don Andrés Llaguno ${ }^{47}$, que he

45 Verso procedente del drama Didone abbandonata, de Pietro Metastasio (1698-1782): «Passó quel tempo, Enea, / che Dido a te pensò. Spenta è la face, / è scielta la catena, / e del tuo nome or mi rammento apena», acto II, escena IV. Estala añade la conjunción $m a$, «pero».

XXXI Chagrin, en francés, «pena, pesar, disgusto, melancolía».

xxxII Guardilla, uso popular de buhardilla, con el significado de «habitación contigua al tejado» (DRAE).

xxxIII Elementos básicos del peregrino: el bordón, ya descrito, y la esclavina, «vestidura de cuero o tela que se ponen al cuello y sobre los hombros los que van en romería» (DRAE).

xxxiv Gambas, en italiano «piernas».

46 Se hace eco Estala de la Real Orden de 24 de febrero de 1791 por la que Floridablanca prohíbe todos los periódicos, a excepción de los oficiales, que eran la Gaceta de Madrid y el Mercurio Histórico y Político. De la quema también se salva el Diario de Madrid, en el que sólo se podían incluir informaciones puntuales sobre pérdidas y hallazgos. La mayoría de los editores de periódicos privados denunciaron la medida, señalando que hasta la fecha se habían mantenido en la más estricta ortodoxia, pero el gobierno denegó o silenció todas las peticiones y quejas, alegando como razón la alarmante proliferación de escritos subversivos.

47 El hermano de Eugenio Llaguno, Andrés Llaguno y Amírola, había nacido el 2 de octubre de 1734 en Menegaray, Araba, y murió en abril de 1791, en Aranjuez. 
sentido mucho porque ya hay un hombre de bien menos en el mundo y ésta es fruta muy rara. No veo ni puedo ver a Bernabéu, porque el maldito debe de andar metido en andróminas ${ }^{\mathrm{XXV}}$ y no se le ve por un cristo ${ }^{\mathrm{XXXVI}}$. Pero ya leí el párrafo de tu carta a Vinagrillo, nuestro corredor ${ }^{48}$, y quedó encargado del asunto. Buscaré el manuscrito de Arguijo y Rioja y te lo enviaré, porque yo ya no tengo gusto para estas cosas. Yo lo tenía entre mis papeles, pero no sé cómo se me ha traspapelado; creo que se lo presté a un conocido y lo recogeré pronto ${ }^{49}$. Diviértete todo lo que puedas hasta que yo vaya, que entonces ya formaremos un plan de vida secreta para ser algo menos infelices. Adiós.

\section{Pedro de Estala}

\section{Carta VI}

Madrid, 24 de mayo de 1791 (PG, VI: 12-13)

Como está el hambre metido en estas andróminas de prevenirse para la oposición, créeme que no tengo tiempo para vacar ${ }^{\mathrm{XXVII}}$ a la amistad ni al amor. Medrados estamos, dirás tú, « ¿conque para contrastar con un D. Santos ${ }^{50}$, un Esguerrilla ${ }^{51}$ y otros aún más misérrimos necesitas de tanto atarearte?». Que no es eso, seor ${ }^{\mathrm{XXXVIII}}$ golilla; no es para mostrar que sé más que ellos, sino para que

Xxxv Andrómina, «embuste, enredo con que se pretende alucinar». Utilízase en plural (DRAE).

XXXVI Ni por un cristo, «locución familiar con que se denota la gran repugnancia que se tiene en condescender con alguna cosa, o la gran dificultad de conseguirla» (DRAE).

48 René Andioc supone que este apodo podría corresponder a un agente de negocios de los Reales Consejos llamado Norberto Acedillo, de ahí que Estala lo llame «nuestro corredor». Cfr. Fernández de MoraTín, Epistolario, p. 130, n. 34. El apodo pudo venir por el color de la tez del sujeto, dado que el vinagrillo era un conocido afeite que, con alto contenido en vinagre, servía para dar blancura a la cara y las manos (DRAE). Moratín nos dice que era «pobre y alegre y muy obsequiador de farsantas». Cfr. ibídem, carta 31.

49 Conjeturo que este «conocido» bien pudiera ser Manuel José Quintana (1772-1857), que fue alumno de Estala en el seminario conciliar de San Carlos de Salamanca, al menos durante dos cursos (17881790). Después del pleito con Ramón Fernández, la Colección de poetas castellanos fue continuada por Quintana, a sugerencia de Estala, de manera que no es improbable que éste también le prestara estos manuscritos para que realizara la edición de Francisco de Rioja y otros poetas andaluces, que sale como el tomo XVIII de la citada Colección (1797). Para las relaciones entre Estala y Quintana, véase mi artículo «Quintana versus Estala: ¿Una historia de pasiones enfrentadas?», en La patria poética. Estudios sobre literatura y política en la obra de Manuel José Quintana, ed. a cargo de F. Durán López, Alberto Romero Ferrer y Marieta Cantos Casenave, Cádiz, Universidad de Cádiz, 2009, págs. 51-64.

XXXVII Vacar, «dedicarse o entregarse enteramente a un ejercicio determinado» (DRAE).

50 Se trata de Santos Díez González (1743-1804), que concursó sin éxito en los Reales Estudios de San Isidro a las plazas de Latín, Filosofía y Lógica. Sin embargo, fue el que imprevistamente ganó la cátedra de Poética.

51 Pudiera tratarse de Joaquín Ezquerra, fundador del Memorial Literario y catedrático de Rudimentos, Sintaxis y Propiedad latina en los Reales Estudios de San Isidro desde el 25 de noviembre de 1775. Cfr. Simón DíAz, Historia del colegio imperial, págs. 330-333.

xxxvIII Seor, contracción popular y castiza de señor. 
el público vea que sé todo lo que hay que saber y sepa cuánto hay que saber. ¿Y le parece a vuesarcé ${ }^{\mathrm{XXXIX}}$ que esto no merece la pena de que me ande yo ahora paseando por la Grecia y asista a aquellos teatros, y oiga de cerca la trompa del buen Meónides ${ }^{52}$ y la lira de Anacreonte y la de Píndaro y la zampoña del saqueado Teócrito; y que de allí pase al Lacio y observe qué arreos y atavíos han tomado las Parnásides ${ }^{\mathrm{XL}}$ en aquel país y qué han ganado o perdido entre los domadores del mundo? ¿Y luego, pasito a pasito, me encaje en la barbarie moderna y revolviendo basureros vea si nos han quedado algunas alhajas y joyas de las susodichas virgos eternos ${ }^{\mathrm{XLI}}$ ? Pues sí señor, todo esto es menester, y todo esto hago y totus in hoc sum ${ }^{\mathrm{XLII}}$. El chiste será que los Radamantos ${ }^{53}$ de esta oposición serán unos badulaques ${ }^{\mathrm{XLIII}}$; yo así lo temo y ya he oído alguna especie ${ }^{\mathrm{XLIV}}$ sobre el asunto que me hace desear que siquiera entre en el número Trigueros ${ }^{54}$, porque a lo menos no es un dómine ${ }^{\mathrm{XLV}}$. Pero iguay ${ }^{\mathrm{XLVI}}$ de los que exciten mi bilis con pedanterías! Melius non tangere, clamo $^{55}$; porque a pesar de su autoridad censoria, oirán lo que no quisieran.

Hame dicho Bernabéu que le envías un fardo de papeles: ya estamos impacientes por verlos. Este buen amigo te quiere sinceramente y, a pesar de los

xxxIx Vuesarcé, apócope de vuesa merced.

52 Es un nombre que se aplica a Homero, bien porque Meonia era el antiguo nombre de Lidia, donde, según algunos, había nacido; bien porque se decía que era hijo de un tal Meón. Cfr. M. C. Howatson, Diccionario abreviado de la literatura clásica, Madrid, Alianza Editorial, 1999.

xL Parnásides, las habitantes del monte Parnaso, el consagrado a las artes, por tanto, las musas.

XL. Perífrasis para aludir de nuevo a las musas. Del latín virgo, «virgen», femenino singular, que Estala castellaniza y juguetonamente combina con un adjetivo en femenino (susodichas) y otro en masculino (eternos).

XLII Totus in hoc sum, «estoy por completo en este asunto».

53 Por metonimia, jueces. Radamanto, hijo de Zeus y Europa, era uno de los tres jueces de los infiernos, junto a Minos y Eaco.

XLIII Badulaques, «metafóricamente y por alusión al guisado que es de poca sustancia, se llama el que es medio bobo, de poca o ninguna actividad y maña, inútil y de ningún provecho» (Diccionario de autoridades).

xLIV Especie, del latín species, «escapársele a uno una especie» es «decir inadvertidamente lo que no era del caso o se debía callar» (DRAE).

54 Cándido María Trigueros era miembro de la Academia de las Buenas Letras en Sevilla y de la de Historia; en estas fechas era bibliotecario segundo en los Reales Estudios de San Isidro y, por tanto, encargado de la sección de manuscritos de esta biblioteca y de organizar los fondos de monedas y medallas que los Estudios poseían. Participó en la cátedra de Historia Literaria y escribió un interesante Discurso sobre el estudio metódico de la historia literaria. Fue además dramaturgo, novelista y poeta. El estudio más documentado sobre esta figura se lo debemos a F. Aguilar Piñal, Cándido María Trigueros, un escritor ilustrado, Madrid, CSIC, 1987.

XIV Dómine, «maestro o preceptor de gramática latina» (DRAE); aquí en sentido despectivo, como sinónimo de persona sin mérito que adopta un tono profesoral y pedante.

XLVI ;Guay!, interjección, jay! (DRAE).

55 Célebre pasaje de la primera sátira del segundo libro de Horacio, donde leemos: «At ille qui me conmorit (melius non tangere, clamo) flebit et insignis tota cantabitur urbe», versos traducidos así por H. Silvestre: «Pero quien me pique (que ni se le ocurra, lo advierto) llorará y será señalado y la comidilla de toda la urbe». Cf. Horacio, Sátiras, II, 1, vv. 44-46, págs. 212-213. 
chismes pasados, no hay novedad en su amistad para contigo. Se está ensayando la ópera seria compuesta por Malo ${ }^{56}$ y puesta en soberbia música por Lidón ${ }^{57}$. Me parece que este drama (aunque débil) va a causar una sensación muy viva, y quizá va a formar época en nuestro teatro, arruinando el de la ópera y abriendo los fundamentos para un teatro lírico español ${ }^{58}$.

Te envío el tomo de poesías manuscritas, que pensé ya no cogerlo. Se están acabando de imprimir las poesías de Burguillos y las de Castillejo ${ }^{\mathrm{XLVII}}$. A pesar de las picardías del portero, le he rogado me envíe las pruebas para corregirlas, porque de otra manera saldrían tan llenas de mentiras y tan estropeadas como las de Góngora, y sería una pérdida irremediable por lo raras que son ambas obras $^{59}$. Pásalo bien. Adiós.

24 de mayo de 91

Damón.

\section{Carta VII}

\section{Madrid, finales del verano de 1791 (PG, XIII: 22)}

No son las oposiciones poéticas las que me han impedido contestarte. Parte los calores, que me han tenido inutilizado para todo, parte un disgusto de la vida que me devora no me ha permitido tomar la pluma. ¿Quieres saber la causa de este fastidio intolerable que me tiene en tanta inacción? Pues no es la falta de salud: yo estoy sano, robusto y sin el menor asomo de achaques. Tampoco

56 Ignacio García Malo (1760-1812), autor de una colección de novelas titulada Voz de la naturaleza (1787-1792) y de algunas interesantes obras de teatro, como Doña María Pacheco, mujer de Padilla (1788), redactó además un breve libreto para ópera basado en La araucana de Ercilla, titulado Glaura y Cariolano, que es el nombre de los araucanos protagonistas. Constaba de ocho escenas divididas en dos actos, y la trama respetaba las unidades de acción, lugar y tiempo. Ha sido trascrito y editado por Dámaso García Fraile a partir del manuscrito conservado en la Biblioteca Nacional de Madrid (Salamanca, Sociedad de Conciertos de Salamanca, 1999). Puede verse en internet: <http://helcom.es/sconciertos/pdf/Lidonarg.pdf >. Esta ópera se estrenó en 1792 en el Teatro del Príncipe para conmemorar el tercer centenario del descubrimiento de América.

57 José Lidón (1748-1827), organista principal y vicemaestro de la Real Capilla de su Majestad. Fue un músico distinguido y de sólida reputación, que compuso más de sesenta obras religiosas. Además de la música para el drama lírico aquí citado, escribió el acompañamiento de El barón, de Leandro Moratín.

58 Distingue aquí Estala la ópera italiana, de enorme éxito en la época, del incipiente teatro lírico español, es decir, lo que después se conocerá como zarzuela.

XLVII Castillejo [corrección mía] Castillejos PG, 13.

59 Las poesías de Tomé de Burguillos y de Castillejo se publican en 1792, en los tomos XI y XIIXIII respectivamente de la Colección de Ramón Fernández, quien, al parecer, no cuenta con Estala para la impresión, pues éste se ve obligado a revisar y corregir los textos a hurtadillas de su socio. La intención de Estala es que no salgan con tantas erratas como las de Góngora, impresas en 1789, en el tomo IX de la citada Colección. 
es la falta de riquezas: mi ambición se limita a una honesta subsistencia y ésta la tengo sin tener que adular a la opulencia insolente, ni que agradecer a los mecenas que ahora se usan. Sano, libre y con algunas conveniencias, me hallo las más veces melancólico y casi siempre lleno de ennui ${ }^{\mathrm{XLVIII}}$, porque me veo aislado en la sociedad, porque me hallo con un corazón sensible ${ }^{60}$ y no tengo en qué emplearle ${ }^{61}$. Pasó aquel tiempo, Aminta, en que los amores metafísicos e imaginarios me entretenían. La razón ya más madura busca un enlace más sólido y constante. Dove trovarlo ${ }^{\mathrm{XLIX}}$ ? ¡Dichoso tú, que lo has encontrado ${ }^{62}$ ! Yo, mísero y mezquino y malhadado, me veo precisado a vivir como un bruto, sin gozar del verdadero placer de un amor que pueda publicarse sin vergüenza: $o$ te felice appicimo ${ }^{\mathrm{L}}$. Yo seré siempre víctima de un pícaro que robe con capa de $\operatorname{amistad}^{63}$, como tú lo has sido hasta aquí, porque nuestro carácter y género de vida nos precisa a vivir siempre en pupilaje ${ }^{\mathrm{LI}}$. Tú de hoy más ${ }^{\mathrm{LII}}$ tendrás en una compañera amable todas las ventajas de la sociedad con todos los placeres más puros. ¡Cuánta envidia ti porto ${ }^{\mathrm{LIII} !}$

XLVIII ennui [corrección mía] ennúa PG, 22.

60 El sintagma «corazón sensible» hizo fortuna en la segunda mitad del siglo XviII. Lo utiliza Rousseau al principio de las Confesiones cuando dice que sus padres le legaron «un corazón sensible que, así como había sido para ellos fuente de felicidad, fue para mí la fuente de todos mis males», porque "antes de pensar, sentí». La misma queja oímos después en la oda «A las musas» de Meléndez Valdés: «¡Oh, qué don tan funesto / es, Fabio mío, un corazón sensible!». El profesor Joaquín Arce acude a las palabras de Manuel José Quintana cuando define al humanista filósofo como el hombre que «reúne al corazón más afectuoso y sensible, la razón más fuerte y despejada» para resumir la esencia del Prerromanticismo. Cfr. J. Arce, «Diversidad temática y lingüística en la lírica dieciochesca», Cuadernos de la Cátedra Feijoo, 22 (1970), pág. 43.

${ }_{61}$ Este ennui, tedio o «fastidio universal», como dirá Meléndez Valdés en un poema de 1794, es un estado de ánimo que declaran padecer a menudo los hombres de la segunda mitad del siglo XviII. Sebold lo ha interpretado como el nombre español del Weltschmerz o «dolor cósmico» propio de los románticos. Cfr. R. P. SEBoLd, «Sobre el nombre español del dolor romántico», en El rapto de la mente. Poética y poesía dieciochescas, Barcelona, Anthropos, 1989, págs. 157-169. Esta tesis ha sido refutada por la profesora Kahiluoto Rudat que, siguiendo a Walter Moser, piensa que más bien se trata de una inquietud de los poetas neoclásicos influidos por el sensualismo de Locke; en ellos se da una combinación de razón, sensibilidad y sentimiento que no es propia del Romanticismo, sino de lo que ella llama «racionalismo sentimental». Cfr. E. M. KAHILUOTO RUDAT, “"Lo prerromántico": una variante neoclásica en la estética y literatura españolas», Iberorromania, 15-16 (1987), págs. 47-69.

XLIX Dove trovarlo?, en italiano «¿Dónde encontrarlo?».

62 Forner iba a casarse con María del Carmen Rodríguez de Carasa, hija del ministro de la Real Junta de Comercio y Fábrica de Cádiz, el 18 de diciembre de 1791. Sobre este asunto puede verse F. Aguilar Piñal, «La boda de Forner», Archivo Hispalense, LXXV, 229 (1992), págs. 541-544.

L O te felice, appicimo, «oh, tú, dichoso...». No existe esta forma verbal en italiano y ninguna de las conjeturas que he barajado me parece fiable, de manera que no estoy en condiciones de aportar una traducción válida.

63 ¿Podrían estas palabras ser una pista sobre la condición sexual del helenista daimieleño?

LI Pupilaje, «estado de aquél que está sujeto a la voluntad de otro porque le da de comer» (DRAE).

LII De hoy más, locución adverbial, «desde este día» (DRAE).

LIII Cuánta envidia ti porto, «cómo te envidio». 
Hice el encargo a Mirtilo con la mayor energía y haré todo cuanto pueda para que se verifique tu consorcio cuanto antes. Pues ya que yo sea infeliz, deseo ver felices a mis amigos, y de ello me redunda cierto placer. Pásalo bien, da mis congratulaciones a tu futura y si i giorni tuoi sono felici ricordati di me. Il tuo fedele, Damón ${ }^{\mathrm{LIV}}$.

\section{Carta VIII}

Madrid, febrero o marzo de 1792 (PG, III: 8)

Supongo que estarás muy indignado contra mí y que en las lecciones de moral que des a la fiscala le dirás muy ponderado de semblanza: «Aprended, madama, lo que son los hombres; yo tenía un amigo, a éste le he escrito dos luengas epístolas y hasta ahora no me ha contestado». «Qué queréis, señor licenciado — responderá la susodicha—, el mundo es mundo ${ }^{\mathrm{LV}}$.» Con esto y levantar los ojos al cielo y dar un hondo suspiro, se dará fin a la sesión en que yo quedaré, a juicio de los dos consortes, por un malandrín. Pues sepan, noramala ${ }^{\mathrm{LVI}}$ para quien así piense, que yo no me duermo en las pajas ${ }^{64}$ y que aunque callo, piedras apaño $0^{65}$, qué sé yo qué más. Tú debes haberte olvidado de lo que es la corte y muy metido a caballero de provincia creerás que no hay más que llegar y zas. Pues dígote que estas cosas se han puesto en un punto muy alto y que para una sesión con don Leandro es menester ir y venir, y al cabo se halla un cristiano con que no está visible su señoría ${ }^{\mathrm{LVII}}$, o que está enfermo, o que ha salido, o alguna de las mil y quinientas respuestas con que están armados los

LIV Frase en italiano con errores gramaticales de concordancia que puede traducirse: «Si tus días son felices, acuérdate de mí. Tu fiel, Damón».

LV Desde que el mundo es mundo, «expresión figurada y familiar para explicar la antigüiedad de una cosa o de su ejecución continua» (DRAE).

LVI Noramala, adverbio de modo, «en hora mala» (DRAE).

64 Dicho popular para expresar que uno está alerta y vigilante. Cfr. J. M. ${ }^{a}$ IribarRen, El porqué de los dichos: sentido, origen y anécdota de los dichos, modismos y frases proverbiales de España, con otras muchas curiosidades (1956), Navarra, Gobierno de Navarra, 1994, pág. 183.

65 Refrán popular recogido, entre otros, por el valdepeñero J. M. Caro y Cejudo, que da la versión latina de Erasmo (Non omnibus dormio, «no duermo para todos») y la explicación de Plutarco sobre el origen de este adagio: «Un hombre llamado Galba, habiendo convidado a Mecenas a comer y habiendo conocido que el tal Mecenas se había enamorado de su mujer por las señas que le hacía, bajó la cabeza un poco como que dormía, y en el ínterin, llegando un criado a la mesa y tomando con todo recato y silencio un vaso de vino que en ella había, él viéndole por estar despierto, aunque parecía que dormía, le dijo: “Oh, mal criado, no sabes que no duermo para todos, sino solamente para Mecenas"». Cfr. J. M. Caro Y Cejudo, Refranes y modos de hablar castellanos, con los latinos que les corresponden y la glosa y explicación de los que tienen necesidad de ella, Madrid, Imprenta Real, 1792, pág. 42.

LVII Su señoría. He desarrollado la abreviatura S. S. PG, 9. 
cerberos $^{\text {LVIII }}$ de los altos señores. Esto cabalmente me ha sucedido, y no me ha sido posible verle ni hablarle en todo este tiempo, por más diligencias que he hecho ${ }^{66}$. Y como de un correo para otro esperaba hablarle y que me diese alguna respuesta, he ido dilatando ${ }^{\mathrm{LIX}}$ escribirte.

En fin, ha venido nuestro héroe Bernabéu, de cuyas negociaciones a tu favor ya estarás informado. Lo que conviene es que ahora que está el hierro caliente no ceses de machacar, esto es, que envíes súbito, súbito, todo lo que tengas dispuesto y déjalo todo al cuidado del insigne Paco, que él sabe más bien que tú y que yo el cómo y el cuándo y de qué modo. Sobre todo chitón, no sea que lo huelan los que te quieren mal y desconcierten todas nuestras medidas. Por lo que hace al cuidado de las impresiones, déjalo de mi cuenta que, aunque cercene unas cuatro horas de las catorce que duermo y un par de las ocho que me paseo y me folgo, no harás falta para nada. Digo esto porque ni Paco ni yo aprobamos que pidas esta licencia para venir, porque queremos que vengas de una, y como il faut.

Damón.

\section{Carta IX}

Madrid, primera quincena de mayo de 1792 (PG, IV: 9-11)

No creas que yo esperase tu epístola para continuar con frecuencia nuestra comunicación, siendo tú el único que ha quedado con quien poder desahogarme y, hallándote ${ }^{\mathrm{LX}}$ igualmente agraviado que yo, en ningún otro podía yo depositar mis quejas mejor que en ti. A la verdad, yo te he hecho el agravio de no contar contigo para nada, pero esto ha procedido de que me habían hecho creer que debía contar con otro para todo y este otro nada es menos que amigo tuyo, bien que a mi entender no lo es de nadie. No es necesario contarte por menor el gran chasco que me he llevado con el tal Abate ${ }^{67}$. Basta decirte que, confiado en las

LVIII Cerbero, aféresis de Cancerbero, «guarda severo e incorruptible». Era un monstruo mitológico con tres cabezas, cola de dragón, lomo erizado de serpientes y una boca que destilaba negra ponzoña. Guardaba la puerta del Hades; su morada estaba al otro lado de la laguna Estigia, en el sitio donde Caronte desembarcaba a las almas de los difuntos.

${ }_{66}$ Moratín había empezado a tener éxito como dramaturgo en 1790, con el estreno en mayo de El viejo y la niña. En febrero de 1792 acaba de poner en escena La comedia nueva en el Teatro del Príncipe, con la que también alcanzó notoriedad y dinero. De ahí que irónicamente ahora Estala lo llame «don Leandro» y lo trate de «su señoría».

LIX Dilatar, «diferir, retardar».

LX hallándote [corrección mía] hallándose PG, 9.

67 Se refiere a Moratín, que era abate desde que se había ordenado de primera tonsura en 1789 para poder percibir un beneficio de trescientos ducados otorgado por Floridablanca en el obispado de Burgos para 
repetidas palabras que me tenía dadas de proporcionarme la protección de su mecenas, he dejado perder la cátedra por no dar un paso, ni querer que nadie hablase por mí ${ }^{68}$. Pero cuando llegó el caso de hallarme sin nada, se escandalizó de que yo aspirase a un beneficio de unos mil ducados por su medio, y sólo consintió $^{\mathrm{LXI}}$ en darme una carta de recomendación para una plaza de seis mil reales que está vacante en la Biblioteca de San Isidro ${ }^{69}$. La tal carta no podía ser más fría ni común, evitando en ella con mucho estudio el decir que era mi amigo, ni que entendía de verso, y sin más esfuerzo en la recomendación que el decir secamente que yo era acreedor a la plaza dicha.

El tal señor no hizo el menor aprecio de ella, ni yo he repetido la instancia, pues para esta representación no necesito de tan alto influjo. No quiso ir conmigo al Sitio, fingiendo varias excusas ${ }^{70}$, y a pocos días después fue con el mayor enemigo mío ${ }^{71}$, al cual presentó en todas partes, y esto porque le había de acompañar en su viaje y excusarle algunos gastos, pues entre sus muchas buenas prendas tiene la avaricia en grado heroico. Se ha ido sin despedirse de mí y

premiar un romance jocoso que le había dedicado; a éste se le añadirá después el beneficio de la villa de Montoro, solicitado por Campomanes para Moratín «en atención a su literatura». Véase una carta fechada el 12 de septiembre de 1790 en AHN, Consejos, 8920, 1.

68 En abril de 1792 Estala conoce la resolución de la oposición para cubrir la cátedra de Poética de los Reales Estudios, que será ocupada por Santos Díez González. En una carta que Moratín envía a Forner, fechada el 25 de abril de ese año, ya le cuenta que Estala ha perdido la cátedra. Cfr. Fernández de Moratín, Epistolario, carta 31.

LXI consintió [corrección mía] consistió PG, 10.

69 La plaza vacante era la que había dejado Isidoro Bosarte de la Cruz (1747-1808), encargado hasta la fecha de la catalogación de los manuscritos. Estala solicita este puesto mediante una instancia que firma el 14 de abril de 1792 (AHN, Jesuitas, leg. 744). El rey pide, a través del conde de Aranda, un informe del bibliotecario primero, Miguel de Manuel, que en su respuesta se muestra partidario de adjudicar la plaza al helenista daimieleño, cuyos méritos están más acordes con el puesto que los de los otros dos candidatos (AHN, Jesuitas, leg. 744). Como indica el profesor Viñao, la selección de los bibliotecarios no se hacía mediante oposición, sino que el Consejo de Castilla proponía al rey las personas más idóneas para que este eligiera. Cfr. A. ViÑAO, «Por un análisis sociocultural de la élite intelectual y académica: los profesores y bibliotecarios de los Reales Estudios de San Isidro (1770-1808)», Bulletin Hispanique, t. 97, 1 (1995), págs. 305-306. Estala se ocuparía de catalogar los fondos manuscritos hasta mayo de 1798 , fecha en que es nombrado bibliotecario segundo gracias al apoyo de Estanislao de Lugo. Alcanzará el puesto de bibliotecario primero en octubre de 1803. Cfr. Arenas Cruz, Pedro Estala, págs. 87-101.

70 Moratín había estado en Aranjuez a primeros de abril, pues el día 9 regresa a Madrid, según anota en su Diario. Allí ha conseguido que el conde de Aranda le financie un nuevo viaje a Francia, hacia donde pretende partir en mayo, el día siete u ocho. Cfr. Fernández de Moratín, Epistolario, pág. 131, carta 30. Si Estala dice que se ha ido sin despedirse de él, esta carta habría que fecharla en la primera quincena de mayo de 1792.

71 Se trata sin duda de Pierre François Chabaneau, profesor de química de los Infantes y después, hacia 1794, profesor de mineralogía y de física en el Real Laboratorio de la Corte. Era uno de los amigos más íntimos de Moratín, cuya casa visita asiduamente y con el que pasea por el Retiro o por el canal del Manzanares, tal como apunta en su Diario. Efectivamente, viaja con él a Francia, pero todavía no he podido averiguar por qué es el peor enemigo de Estala. Cfr. R. ANDIOc, edición del Epistolario de Moratín, ed. cit., págs. 147-149, n. 8. 
dejando sus papeles en poder de Melón ${ }^{72}$ para que los entregue a Bernabéu, con quien se ha portado tan bien como conmigo, pues habiéndole dejado por agente de su pretensión, no ha dado ni un paso ${ }^{73}$. Ya te habrá dicho Tejada ${ }^{74}$ cómo no se ha entregado ninguna de las cartas que has dirigido por su conducto, y que mi parecer es que escribas a Tejada encargándole recoja tus papeles para hacer de ellos el uso que te parezca.

Esta $^{\mathrm{LXII}}$ es, en suma, la historia de mi mala andanza por creer ciegamente en la amistad de un hombre que tiene por máxima usar de los hombres como de las cosas, cada cual para su uso diferente, pero sin aficionarse ni molestarse por nadie. Mi amistad para con él ha llegado hasta el mayor extremo, pues ni tú ni nadie creerá lo que yo he hecho por él. Su correspondencia ha sido la más ingrata; y lo que más me hiere es haber sabido que procede de un sumo desprecio de ti y de mí, creyéndose el único hombre por todos títulos, y que nos hace demasiado favor en dejarse servir de nosotros. Él está sumamente desacreditado en el público, pues grandes y chicos creen que ha vendido a Cabarrús, a quien lo debe todo. Por lo menos, si no le ha hecho traición positiva, es inexcusable su omisión en no haber hablado una palabra por él ${ }^{75}$, teniendo

72 Juan Antonio Melón (1758-1843) era otro de los amigos más íntimos de Moratín. Estala lo conocía porque ambos habían trabajado muy cerca del obispo de Salamanca e inquisidor general, Felipe Bertrán, que, como ya he dicho, funda en 1779 el seminario conciliar de San Carlos de dicha ciudad, institución de la cual Melón es nombrado vicerrector en 1781. En ese año, como el propio Melón cuenta, Estala se lo presenta a don Leandro: «Le conocí en la calle de Alcalá, cerca del Prado, yendo yo de paseo con don León de Arroyal [...], porque se arrimó a nosotros con dos jóvenes escolapios, Estala y Navarrete, con quien él había jugado en su niñez en el barrio de doña María de Aragón [...]. Desde entonces concurríamos los dos casi diariamente a la celda del padre Estala hasta cierta hora de la noche que cerraban el convento». Cfr. MeLón, «Desordenadas y mal digeridas apuntaciones», f. 2 v.

73 Francisco Bernabéu tenía un padre anciano, cuatro hermanos y nueve hermanas solteras a quienes mantenía con su sueldo de guardia de Corps. Por estas fechas encarga a varios de sus amigos que utilicen sus influencias para poder obtener un empleo mejor remunerado y de desempeño más acorde con su obesidad. Estos datos se encuentran en una carta que dirige a Forner, y que éste repite en un romance burlesco que le envía a Godoy. Cfr. Cueto, Poetas líricos del siglo XVIII, págs. 328-329. Estala se hace aquí eco de la supuesta ingratitud de Moratín hacia Bernabéu.

74 René Andioc identifica a este amigo de Moratín con Manuel Antonio Sáenz de Tejada, que defendió El viejo y la niña cuando esta comedia recibió los furibundos ataques de Fulgencio de Soto (Cristóbal Cladera) en julio de 1790. Cfr. Fernández de Moratín, Epistolario, pág. 127, n. 2.

LXII Esta [corrección mía] Este PG, 10.

75 Era Francisco Cabarrús uno de los principales asesores de Carlos III en asuntos económicos. Partidario al principio de reformas liberales dentro del régimen absolutista, poco a poco radicaliza su actitud hacia posiciones claramente democráticas, que se plasman en el Elogio de Carlos III, leído el 25 de julio de 1789 ante la junta general de la Real Sociedad Económica de Madrid. A raíz de esto, es denunciado a la Inquisición y hecho preso. Sobre la evolución ideológica de Cabarrús puede verse J. A. MARAvaLL, «Cabarrús y las ideas de reforma política y social en el siglo XVIII», Revista de Occidente, VI (1968), págs. 273-300. Moratín había sido su secretario y viajado con él a París en 1787. En el proceso contra Cabarrús, don Leandro fue oído como testigo en varias ocasiones; en este sentido, sus declaraciones resultaron, al parecer, imprecisas, seguramente porque temió correr la misma suerte que él. Como apunta R. Andioc, «la sospecha de traición se debió sin 
tanta proporción ${ }^{\mathrm{LXIII}}$. Lo cierto es que ha acelerado su viaje porque venía Cabarrús a Madrid, y que se marchó la víspera de la venida de éste. Basta de Abate, por ahora, que es menester muchas cartas para decirlo todo.

Yo estoy esperando me den la plaza de la Biblioteca de San Isidro ${ }^{76}$. Ya te habrán escrito sobre la nueva Academia: yo soy académico de número ${ }^{77}$, y he entrado únicamente porque entra Zavala ${ }^{78}$. Ya me entenderás. Entra tú también. Adiós.

Damón

\section{Carta X}

Madrid, mayo o junio de 1792 (PG, XIV: 23-24)

Piensas bien en sacar la obra de manos de Melón ${ }^{79}$. Que se presente cuanto antes, porque Bernabéu tardará en venir y no conviene perder tiempo. El medio más acertado será que escribas a Melón por mano de Tejada, para que le entregue la obra sin decirle que es para mí, porque yo en la apariencia corro con Melón lo mismo que antes, pero en el fondo estamos poco satisfechos uno de

duda a que Moratín no fue comprehendido en la proscripción de los amigos del conde». Cfr. FernándEZ DE Moratín, Epistolario, págs. 132-133, n. 4 y 8.

LXIII Proporción, «disposición u oportunidad para hacer o lograr una cosa» (DRAE).

76 El nombramiento será el 2 de julio de 1792.

77 Se trata de la Academia Poética llamada de «los pastores de Manzanares», promovida y animada por el librero y editor Gabriel Sancha. En la solicitud que se presenta al Consejo de Castilla para la aprobación de los estatutos figura el nombre de Estala sobrepuesto, como si hubiera sido inserto en el último momento. Los demás solicitantes eran Vicente Rodríguez de Arellano, Gaspar de Zavala, Juan Pons Izquierdo, Joaquín de Flórez, José Virués y Joaquín Barón. En los citados estatutos se indica que los académicos de número o de primera clase serán doce, entre los cuales «se nombrarán todos los empleos de la Academia y ocuparán en las juntas los primeros asientos según su antigüedad». Traerán «trabajadas las piezas que se les hubiese encargado» y «deberán huir siempre de toda rivalidad, división, enemistad o cualquier otro motivo que sea capaz de alterar la unión y buen orden y siempre deberán procurar con todas sus fuerzas los adelantamientos y progresos del establecimiento». Junto a ellos, estaban los académicos de mérito o de segunda clase y, finalmente, los académicos de honor.

Los trámites para la aprobación de los estatutos fueron largos. Se presentan al Consejo de Castilla el 18 de enero de 1791; sin embargo, pasa casi año y medio hasta que el fiscal se hace cargo de la solicitud. El 31 de agosto de 1793 pide informes a don Juan López de Sedano y a don Francisco Vázquez de Cayetano, que envían sus respuestas positivas el día 16 de noviembre. El fiscal concede finalmente el permiso para la constitución de la Academia Poética el día 19 de ese mes (AHN, Consejos, leg. 1519). Pueden verse también las breves notas de J. Simón Díaz, «El helenismo de Quevedo y varias cuestiones más», Revista de Bibliografía Nacional, VI (1945), págs. 110-111.

78 Gaspar de Zavala y Zamora (1762-¿1824?), escritor muy prolífico que se hizo famoso con una serie de dramas sobre Carlos XII, rey de Suecia, entre otros muchos. Algunas de sus obras han sido analizadas por G. CARnero, Estudios sobre el teatro español del siglo XVIII, Madrid, Castalia, 1988, cap. 2.

79 Forner había enviado a Moratín copias de algunas de sus obras con el fin de que éste, que tenía tan buenos contactos en la corte, le buscase el apoyo de sus mecenas. Cuando sale de viaje deja todos sus papeles, también las obras de Forner, en poder de Melón. 
otro por varias causas. Luego me escribes una carta para don Luis, a quien tengo por más conveniente hablar primero, para que se entregue la obra por su medio o con su recomendación, porque don Manuel está inaccesible y por más que me cansase en ir y venir, jamás le podría hablar a satisfacción ${ }^{80}$. Yo no tengo inconveniente en hablar a don Luis y en hablarle como conviene y creo que lograré interesarle, porque aunque el señor Abate estaba repitiendo constantemente que don Luis no te estimaba y que tenía grandes quejas de ti, creo que sería con el fin de que yo no me valiese de ti para nada. Lo que ciertamente creo es que no se habrá descuidado en desacreditarte siempre que haya tenido ocasión. Este juicio no es nada temerario, pues sé que se ha portado así conmigo y eso que no podía yo perjudicarle con los dos hermanos y, sin embargo, me consta que ha dicho que yo no soy para nada, que no quiero trabajar, que todo cuanto tengo es incorrecto, débil y defectuoso, y otros elogios de esta naturaleza. Sé que don Luis tenía ganas de conocerme y que a él y a Bernabéu les dijo varias veces que me llevasen a su casa, pero jamás llegó el caso y tengo evidencia que esta omisión no consistió en el pobre Bernabéu, a quien compadezco.

A propósito de Bernabéu, el pobre se marchó dejando encargada su pretensión al Abate, el cual no ha dado un paso sobre ella; y sé por Izabuniaga ${ }^{81}$ que, habiéndole manifestado los apuros en que se hallaba por no tener un cuarto y estar sumamente empeñado, no fue para ofrecerle, siquiera de cumplimiento, el menor socorro. Así que tendré el mayor gusto en introducirme con don Luis precisamente por tu medio y hacer por ti y por Bernabéu los mejores oficios, pues cuando lo sepa el tal viajante, sé que lo sentirá vivamente ${ }^{82}$. Tengo entendido que don Luis está muy quejoso de él porque luego que se vio acomodado, se fue

80 Los hermanos Godoy.

81 No he encontrado a nadie que responda a este nombre y que esté relacionado con Estala o con sus amigos. Conjeturo que Pérez de Guzmán pudo transcribir mal el nombre y leer Izabuniaga donde quizás ponía Luzuriaga. El médico Ignacio María Ruiz de Luzuriaga (1763-1822) estuvo muy vinculado al grupo de Moratín; el dramaturgo lo menciona en su Diario (11 de abril de 1792) y varias veces en su Epistolario (cartas 32, 245, 233). Se interesó por la nueva higiene y la medicina experimental —conocida y aprendida en Edimburgo_-, que le lleva a estudiar la absorción del oxígeno en la respiración. Publicó un estudio Sobre el cólico de Madrid (1796).

82 Moratín se fue a Francia en mayo de 1792 sin haber hecho, al parecer de Estala, uso de sus influencias para que Bernabéu consiguiera lo que pretendía; sin embargo, por su epistolario sabemos que no se olvida del guardia de Corps y siempre que puede pide noticias del caso a Melón. Por ejemplo, el 26 de julio de 1793 escribe: «Dime, por Dios, si han dado algo a Benabéu y qué se hace, pues nada he sabido de él ya ha más de seis meses» (carta 41, pág. 157). No obstante, hasta agosto de 1794 no escribe una carta al duque de la Alcudia en la que recomienda la solicitud de Bernabéu para cambiar de trabajo (carta 49, págs. 175-176). En mayo de 1795 Moratín escribe: «No sabía palabra de que al buen Bernabéu le hubiesen sacado de trabajos, porque no me escribe jamás; dale un abrazo de mi parte y asegúrale de mi invariable amistad» (carta 57, pág. 193). Y todavía en septiembre de ese año: « ¿Por qué no me escribe Bernabéu? No puedo creer que se haya olvidado de mí. De Estala no digo nada: no sabe él cuánto me alegro de que viva feliz» (carta 58, pág. 196). 
retirando de su trato; yo le echaré algunas indirectas y procuraré hacer por tan buen amigo los mismos oficios que él ha hecho por mí. Adiós.

Tu Damón.

\section{Carta XI}

Madrid, 6 de julio de 1792 (PG: XIX: 31-32)

Habrás extrañado mi tardanza en contestarte, pero me he detenido porque la cosa se iba dilatando de un día para otro. Vino nuestro Paco, nuestro buen Paco, destinado a ser bienhechor incansable de abates ingratos, pues si Moratín lo ha sido mucho, no le ha ido en zaga Cladera ${ }^{83}$, a quien después de haberle dado un canonicato (que él ha hecho beneficio simple) que le vale cuarenta mil reales $^{\mathrm{LXIV}}$, y haberle sacado licencia para viajar ad libitum ${ }^{\mathrm{LXV}}$, ya le desconoce. En fin, dejemos pasar estas cosas, que no tienen fin, y vamos a tu asunto. Nos presentamos a don Luis, que me recibió $d a$ amico $^{\mathrm{LXVI}}$; entregámosle la obra ${ }^{84}$, hablé como un energúmeno, hice reír mucho a don Luis, quedaron estupefactos de la Dedicatoria, no se les escapó la finura con que está hilada, y quedó don Luis en presentarla mañana a su hermano y conseguir los tres artículos preliminares (perdóname el terminillo diplomático, que algo se me había de pegar del Mercurio $^{85}$ ), es decir, que se aceptará, se recomendará a Fita, juez

83 Se trata del presbítero mallorquín Cristóbal Cladera (1760-1816), doctor en derecho canónico y penal por la Universidad de Valencia. Afincado en Madrid, dirigió hasta 1791 un periódico, el Espíritu de los mejores diarios literarios que se publican en Europa, donde recopilaba textos seleccionados de diversas revistas europeas. Sobre Cladera pueden verse algunos datos curiosos en los trabajos misceláneos de Simón DíAz, «El helenismo de Quevedo», págs. 113-118; y R. ANDIoc, «De algunos enigmas histórico-literarios», en Estudios dieciochistas en homenaje al profesor José Miguel Caso González, Oviedo, Instituto Feijoo de Estudios del Siglo XVIII, 1995, pág. 63 y ss. Aunque se distinguió como traductor, se le recuerda por la dura crítica que, camuflado tras Fulgencio de Soto, redactó contra El viejo y la niña (Diario de Madrid, 19 de junio de 1790, núm. 371, págs. 148-171), a la que contestó el propio Moratín en los núms. 375 y 376 del mismo periódico.

LXIV Cuarenta mil reales. [He desarrollado la abreviatura] 40 mil rs. PG, 31.

LXV Ad libitum, «a deseo».

LXVI De amico, «como un amigo, con amistad».

84 Se trata de la primera versión del Discurso sobre el modo de escribir y mejorar la historia de España, dedicado a la reina María Luisa. Nunca llegó a publicarse en vida de Forner, pese a los desvelos de Estala y el empeño de los hermanos Godoy. El texto definitivo no vio la luz hasta 1843, cuando lo editó Luis de Villanueva con el título de Reflexiones sobre el modo de escribir y mejorar la historia de España. Después ha sido reeditado por F. López. Véase J. P. Forner, La crisis universitaria. La historia de España (dos discursos), Barcelona, Labor, 1973.

85 Estala era uno de los compositores o traductores del Mercurio Histórico y Político, periódico de inspiración oficial elaborado con noticias extractadas de la prensa extranjera. En estas fechas era dirigido por José Clavijo y Fajardo. El helenista daimieleño se incorpora a la plantilla en el verano de 1790, recién llegado de Salamanca, una vez abandonada la cátedra de Retórica y Griego. Conocemos este dato porque el exjesuita Juan Clímaco Salazar le comenta a Forner en una carta desde Subiaco (Italia): «Me dice Gregorio que esperan 
de Imprentas ${ }^{86}$, para que yo la censure ${ }^{87}$, y se solicitará se imprima a costa del rey, y a beneficio in totum ${ }^{\mathrm{LXVII}}$ del autor. Don Luis te estima en forma, quidquid abatucci dixerint ${ }^{\mathrm{LXVII}}$, y en prueba de ello nos dijo que, si hubiera ido este año a Extremadura, como pensaba, se hubiera alargado a Híspalis sólo por darte in amplexu $^{\mathrm{LXIX}}$. Se habló de tu consorcio, se ponderaron las buenas partes de tu cara mitad y sólo se dudó si tu paternidad era efectiva ${ }^{88}$. Lo que yo deduzco de lo mucho que hablamos es que si aprietas ahora la mano enviando todo lo que tengas trabajado, es muy posible que te traigan antes de mucho. De Moratín no se habló ni una palabra.

Su majestad (que Dios guarde) ${ }^{\mathrm{LXx}}$, sin recomendaciones de abates, se ha dignado hacerme bibliotecario de San Isidro en segundo para espulgar los manuscritos y hacer un índice razonado de lo bueno que allí haya ${ }^{89}$. La renta no es más que seis mil reales ${ }^{\mathrm{LXXI}}$, pero soy jefe en mi departamento, no dependo de nadie, entro y salgo, trabajo o no, según me place; este trabajo es muy de mi gusto, muy divertido y me proporciona lucirme. Si hallo algo exquisito, te lo participaré.

Villafañe ha muerto; han hecho director interino a Cano Manuel y es regu-

Vdms. en Madrid a nuestro común y buen amigo Estala; y desde que él lo toma entre manos empezamos a leer el Mercurio Histórico y Político de Madrid». Cfr. Cartas y papeles varios de Juan Pablo Forner, en la Biblioteca Nacional de Madrid, ms. 21885, f. 95r.

86 José Antonio Fita Capella había ocupado diversos cargos en Valencia, de donde ascendió, en 1785, a alcalde de Casa y Corte; nombrado en 1788 tercer fiscal del Consejo, pasa en 1791 a ocupar el puesto de fiscal primero con voto, y, al año siguiente, se le nombra consejero de Castilla y de la Cámara, puesto en el que también se concentraban las funciones de juez de imprentas.

87 Era frecuente que el Consejo de Castilla encargara a personas competentes en las diversas materias (literatos, académicos, filósofos, profesores, etc.) la redacción de dictámenes de censura para conceder o no las correspondientes licencias de impresión. En este sentido, los bibliotecarios de los Reales Estudios cumplieron a menudo esta función por encargo de su director, Estanislao de Lugo. Pueden verse los dictámenes de censura emitidos por el helenista manchego en mi trabajo Pedro Estala, vida y obra, ed. cit., págs. 479-501.

LXVII In totum, «totalmente».

LXVIII Quidquid abatucci dixerint, «no importa qué hayan dicho los abates» (esto es, Moratín y Cladera). LXIX In amplexu, «un abrazo».

88 La esposa de Forner estaba embarazada en estas fechas y daría a luz en octubre un varón, Antonio Agustín Forner.

LXX Su majestad (que Dios guarde). [He desarrollado la abreviatura] S. M. (q. Dios g.) PG, 32.

89 Estala acaba de recibir, el día 2 de julio, la noticia de su nombramiento como bibliotecario tercero de los Reales Estudios de San Isidro. Allí se encargará de continuar los índices de manuscritos «en los mismos términos y con la misma consignación que tenía Isidoro Bosarte (6000 reales anuales)». Cfr. A. MigueL Alonso, La biblioteca de los Reales Estudios de San Isidro, Madrid, Universidad Complutense, 1992, págs. 204-205. Cuando apunta que es en segundo no quiere decir que sea el segundo bibliotecario, pues este puesto lo ocupaba Cándido María Trigueros, sino que su trabajo ocupa un lugar secundario respecto a los dos más importantes. Hasta la fecha, el encargado de la sección de manuscritos había sido el bibliotecario segundo, y como tal, guardaba la llave. Con todo, cuando Estala ocupa el puesto de bibliotecario tercero, toda la responsabilidad recaerá sobre él, pues se le entrega la llave, sin que el propio Trigueros supiera nunca por qué razón dejó de tenerla. Cfr. Aguilar Piñal, Un escritor ilustrado, págs. 101-102.

LXXI Seis mil reales. [He desarrollado la abreviatura] 6 mil rs PG, 32. 
lar que hagan en propiedad algún golilla ${ }^{90}$. Yo me alegraría que lo fueses tú, o Miguel de Manuel $^{91}$, pero como es un bocado bobo, los consejeros, que son los que han de hacer la propuesta, harán de modo que se quede entre ellos.

Hoy se ha cubierto de grande el duque de la Alcudia ${ }^{92}$. El conde de Aranda ha devuelto a Porlier ${ }^{93}$ todos los asuntos que se había reservado Floridablanca y entre ellos los Estudios de San Isidro y la Universidad de Valencia, y Porlier ha remitido al Consejo todo lo perteneciente a ésta ${ }^{94}$.

Moratín se mantiene en Burdeos instruyéndose en las ciencias y artes con las meretriculas triobolarias ${ }^{5}$. He tenido hasta ahora el honor de que no se acuerde de escribirme. Por casualidad he encontrado el borrador de la epístola comendaticia $^{\mathrm{LXXII}}$ para aquel señor; te la envío para que te sirva de modelo para recomendar a tus amigos, pero me la devolverás, porque no quiero carecer de una prueba tan auténtica y expresiva de su amistad. Adiós. Tuyo,

\section{Damón.}

A 6 de julio de 1792.

90 Manuel Villafañe y Flórez era el director de los Reales Estudios; a su muerte es nombrado director interino Antonio Cano Manuel, pero los pronósticos de Estala no se cumplen. Aranda nombra, por Decreto de 24 de agosto de 1792, director al monje benedictino e inquisidor general, Manuel Abad Lasierra, de talante liberal y erudito. Sin embargo, es cesado a los pocos meses, pues, una vez en el poder, Manuel Godoy designa, en febrero de 1793, director de la prestigiosa institución escolar a Estanislao de Lugo. Vinculado al círculo de la condesa de Montijo y reconocido jansenista, era el hombre más adecuado para desarrollar la política ilustrada que el poderoso ministro quería promocionar.

91 Miguel de Manuel y Rodríguez era el bibliotecario primero de los Reales Estudios desde 1788; como ya he dicho, gracias a su recomendación (AHN, Jesuitas, leg. 744), Estala es contratado para continuar el índice o catálogo de los manuscritos.

92 Alude Estala a una de las ceremonias más importantes en la extraordinaria y meteórica carrera de Manuel Godoy. Después de hacerle donación perpetua de la dehesa de la Alcudia, con sus derechos, frutos, rentas, emolumentos y regalías correspondientes, el rey lo nombra grande de España de primera clase con el título de duque de la Alcudia. Esta concesión iba acompañada del acto de cubrirse en presencia del rey, «el de significado más profundo para quienes obtenían la más alta categoría de la nobleza castellana», como apunta Emilio La Parra. La ceremonia tuvo lugar en palacio el viernes 6 de julio a las 11 de la mañana. Cfr. E. La PARra, Manuel Godoy, la aventura del poder, Barcelona, Tusquets, 2002, pág. 86.

93 Antonio Porlier y Sopranis, oriundo de La Laguna (Tenerife), era, desde 1790, secretario universal del Despacho de Gracia y Justicia de Indias.

94 El conde de Aranda había sido nombrado primer secretario de Estado el 28 de febrero de 1792, para sustituir al conde de Floridablanca, designado por Carlos III en 1777 y mantenido en el poder por su hijo Carlos hasta esta fecha. Durante el breve periodo en que ocupó el poder, Aranda devolvió a sus respectivos ministerios o secretarías algunas de las muchas competencias que Floridablanca había incorporado a la de Estado, producto de su avidez «por asumir el despacho de los asuntos que le interesaban, sustrayéndolo a sus correspondientes secretarías». Cfr. LA PARRA, Manuel Godoy, págs. 154-155. Aranda ocupará este puesto hasta noviembre de 1792, fecha en que es sustituido por el influyente Manuel Godoy.

95 Meretriculas triobolarias, literalmente meretricillas de tres óbolos, es decir, baratas y de baja estofa. Sobre estas consuetudinarias visitas a los prostíbulos de Burdeos deja constancia el propio Moratín en su Diario. En sus aventuras le acompaña Pierre François Chabaneau, al menos hasta primeros de junio de 1792, fecha en que se despide de este amigo. Cfr. Fernández de Moratín, Epistolario, págs. 147-149, n. 8.

LXXII Comendaticia, «aplícase a la carta o despacho de recomendación que dan algunos prelados» (DRAE). 


\section{Carta XII}

Madrid, septiembre de 1792 (PG, V: 11-12)

Me escribiste sobre la traducción de la Ilíada ${ }^{96}$; he visto la copia que trajo Trigenon $^{97}$, tan estropeada que no la conocerá la madre que la parió. Pero este proyecto debe quedar para cuando vengas, pues por ahora harto harás en salir con lo que tienes entre manos. Lo mismo te digo del papel sobre los toros ${ }^{98}$; después de hablar de ello ${ }^{\mathrm{LXXIII}}$, fallamos que no te es decente ni útil que salga como una especie de folleto; mejor será que lo reserves para imprimirlo con los demás papeles jurídicos que dices tienes compuestos.

El abate viajante ha estado a pique de ser empalado en París el diez de agosto en el masacre ${ }^{\mathrm{LXXIV}}$ que ya habrá llegado a tu noticia ${ }^{99}$. En fin, tuvo la fortuna de escapar y se ha marchado a Londres, donde se halla a la entrada de un invierno que ya sabes lo que es allí, sin entender a nadie ni poderse dar a entender, sin dinero y sin más ayuda de $\operatorname{costa}^{\mathrm{LXXV}}$ que mil reales al mes, con lo que no tiene ni aun para carbón de piedra ${ }^{100}$. Ahora solicita venirse, y aun al

96 Por lo que aquí dice Estala, Forner estaba trabajando en una traducción del poema homérico, aunque su versión debió perderse porque no he encontrado referencia alguna en las obras del fiscal extremeño. De hecho, la copia que Forner envía para que sea publicada en Madrid llega muy «estropeada» sin que, no obstante, Estala especifique la naturaleza o causa del daño o defecto.

97 No he conseguido identificar a este personaje. En un principio pensé que podía tratarse de un apelativo familiar, o de un apodo secretamente compartido, para referirse a Trigueros, pero pronto descarté esta posibilidad porque no me cuadraba que este enemigo antiguo y confeso de Forner fuera quien llevara la citada traducción a Estala. Por lo demás, el propio D. Francisco Aguilar Piñal, profundo conocedor de la vida y la obra del poeta sevillano, me ha confirmado que no ha encontrado referencia alguna a este mote referido a don Cándido. Se trata, sin duda, de un personaje que simplemente cumpliría funciones de correo entre Sevilla y Madrid.

98 Referencia al Informe sobre la licitud y conveniencia de las corridas de toros. El manuscrito, fechado en Sevilla el 19 de febrero de 1792, se encuentra en la Biblioteca Colombina y fue publicado por Luis Toro Buiza en el Archivo Hispalense, núm. 16, 1946, págs. 233-243.

LXXIII de ello [corrección mía] en ello PG, 11.

LXXIV Adaptación castellana del francés le massacre, de ahí el artículo masculino.

99 Moratín vivió los sangrientos motines que se produjeron la noche del 9 al 10 de agosto de 1792 en la capital francesa, cuando fue asaltado el palacio de las Tullerías. El rey pierde todos sus poderes y tres días después la familia real es trasladada a la prisión del Temple. En enero de 1793 Luis XVI sería ajusticiado y en octubre, su esposa María Antonieta.

LXXV Ayuda de costa, «socorro en dinero para costear en parte alguna cosa» (DRAE).

100 Moratín llega a la capital de Inglaterra el 27 de agosto de 1792, según anota en su Diario. Informa de su situación a Melón, casi en los mismos términos en que seguramente le habría escrito a Estala: «Ayer llegué a Londres [...]; la lengua es infernal y casi pierdo la esperanza de aprehenderla; me he metido de rondón en una casa que me cuesta una muela cada día; no sé a dónde iré a parar; ya te avisaré; entre tanto, mira en qué estado tiene tu primo la remesa que debe enviarme, pues mi bolsa está ya in extremis». Sin embargo, casi dos meses después, su ánimo es mucho mejor: «¡Cómo bebo cerveza! ¡Cómo hablo inglés! ¡Qué carreras doy por Hay-Market y Covent-Garden [sic]! ¡Cómo me solicitan ad turpia! ¡Cómo me ha herido el ceguezuelo 
mes de estar en Francia me escribió que ya le pesaba el viaje ${ }^{\mathrm{LXXVI}}$, y que viese el modo de que pudiese volver con algún pretexto decente y con un nuevo empleo lucrativo. Yo no le he respondido, ni pienso en sacar carta suya, aunque más me escriba. Basta de chascos; sería necedad en mí tratarle bajo el pie que antes.

Yo tengo el empleo más propio de mi genio que se pudiera hallar en toda la baraja. No me da ninguna sujeción, hay lo suficiente para socorrer las necesidades que la naturaleza y la costumbre nos hacen indispensables; gozo de una tranquilidad inalterable y vegeto como una máquina. No compro ningún libro, porque he hallado por mi cuenta que hacen mejor un quilo los perniles gallegos que los tomos de Platón o Aristóteles; nada escribo, ni pienso escribir, porque no quiero dar ganancia a pícaros con mi sudor.

Al cabo se ha impreso el Dutens porque mi paisano Romero lo ha costeado $^{101}$, y de un trabajo tan largo y penoso he sacado la suma de unos mil reales; puedo quedar arregostado a trabajar. Tú sí debes trabajar para salir de esa arrastrada vida; $e$ poi ${ }^{\mathrm{LXXVII}}$, cuando hayas pillado una cosa cómoda, deberás irte muy despacio en esto de bujarrear ${ }^{\mathrm{LXXVIII}}$ papel. Así pienso ahora; quizá cuando vengas me pegarás ${ }^{\mathrm{LXXX}}$ el maldito contagio de escriborrotear como marras ${ }^{\mathrm{LXXX}}$, pero lo holgado de ahora, no me lo quitarás.

Yo soy tardío en coger la pluma, pero ya ves cómo me desquito. Muy fatigada siento la humanidad, y si no fuese por cierta persona que hace conmigo los oficios que hará contigo la fiscala, Dios sabe cómo podría yo expeler el mal humor que me causa el escribir tanto. Adiós. Tu buen

\section{Damón}

rapaz con los ojos zarcos de una esplieguera! Y, sobre todo, ¡cómo oigo misa!». Cfr. Fernández de Moratín, Epistolario, cartas 32 y 33, págs. 134 y 138.

LXXVI el viaje [corrección mía] del viaje PG, 11.

101 Se trata de las Reflexiones sobre el origen de los descubrimientos atribuidos a los modernos, de Louis Dutens, una versión hecha por Estala en 1787 a partir del cotejo del original francés, la edición inglesa y una traducción anterior hecha por José Fernández de Castro. Este trabajo lo enfrentó a Ramón Fernández, que le puso un pleito acusándolo de haberle robado la traducción. Como consecuencia, la impresión se demoró varios años, hasta que el manuscrito fue comprado por Juan Antonio Romero, intérprete de lenguas orientales en la Real Biblioteca y profesor en los Reales Estudios de San Isidro, también oriundo de Daimiel como indica Estala. Romero costea la edición y se atribuye la traducción, que es impresa por Benito Cano en 1792. El proceso y resolución de este asunto ha sido tratado por ANDIOC, «Ramón Fernández», ed. cit., y por mí en el libro Pedro Estala, págs. 427-435.

LXXVII E poi, «y después».

LXXVIII Bujarrear, vulgarismo por aféresis: dibujar > dibujarrear > bujarrear, como sinónimo despectivo de escribir.

LXXIX pegarás [corrección mía] pagarás PG, 11.

LXXX Como marras, «como antaño» (DRAE). Propio del estilo familiar y bajo, «marras es un adverbio de tiempo para significar el que ya pasó y en que sucedió algún caso particular, como la "noche de marras"» (Diccionario de autoridades). 


\section{Carta XIII}

Madrid, 16 de octubre de 1792 (PG, VIII: 16-17)

Hombre, no eches a rodar toda la máquina por tu pereza o descuido en enviar los papeles consabidos, de los cuales depende tu libertad. Bernabéu los espera con impaciencia y yo ni más ni menos. Éste tiene entablada una pretensión para su acomodo y para volver por el honor de su nobleza, que ha sido ultrajada en su pueblo. A este fin, por consejo del duque, ha formado una representación y a instancias del mismo quiere sacar su genealogía en limpio ${ }^{102}$, cuyos documentos paran en poder de don Miguel Vidal, que vive calle de los Preciados, el cual dice que fue muy amigo de tu padre y que lo es tuyo. Ahora bien, el pobre Paco, como está escaso de maravedises ${ }^{\mathrm{LXXXI}}$ no quisiera comprometerse si esto le ha de costar más de 50 doblones ${ }^{103}$, pues si no pasa de esta cantidad, podrá costear la cosa por sí; pero si asciende a más, necesita de tu auxilio, en quien únicamente tiene confianza para salir de estos apuros. Por ende, me ha encargado te escriba demandando tu favor para este empeño y suplicándote, como te suplico en nombre de mi parte, que escribas al susodicho Vidal recomendándole la prontitud y ofreciéndole que sales por responsable de lo que importe. La cosa es de la mayor importancia para Bernabéu, por muchos títulos ${ }^{\text {LXXXII: }}$ el mismo rey ha hablado a éste diciéndole «ya sé que tu padre es hombre de

102 Tal como explica Santiago Aragón Mateos, los históricos privilegios de la baja nobleza en las pequeñas villas inspiraban en estas fechas ya poco respeto; los hidalgos se sienten ultrajados por las nuevas oligarquías de labradores acomodados que van formándose en los concejos y para las que la sangre ya no tiene ningún valor. Sin duda, éste era el caso del extremeño Francisco Bernabéu, que se ve obligado a pleitear y a solicitar el favor de Godoy para restablecer su condición de caballero hidalgo, puesta en entredicho en su pueblo. Véase S. Aragón Mateos, «La difícil supervivencia de la baja nobleza», en La nobleza extremeña en el siglo XVIII, Mérida, Consejo Ciudadano de la Biblioteca Pública Municipal, 1990, págs. 112-129.

LXXXI Maravedises, uno de los tres plurales que se admiten para esta palabra, junto a maravedís y maravedies.

103 El doblón era una moneda antigua de oro, que en el siglo XviII equivalía a dos escudos. No puede establecerse una equivalencia continua entre doblones o escudos y reales, puesto que los doblones y escudos son monedas de oro y plata y su valor en reales (moneda de plata y cobre) dependía de la equivalencia de estos metales en cada momento, es decir, que el sistema monetario no funcionaba como ahora, con un valor fijo para todas las monedas, sino que cada una tenía el suyo y la equivalencia con las demás dependía fundamentalmente de su precio de mercado y de la valoración de las aleaciones que las formaban. En todo caso, parece que los doblones y escudos, por ser monedas de mucho valor, no se utilizaban para transacciones de pequeña cuantía o cuestiones domésticas, para lo que se utilizaba el real o el real de vellón. Debo estas preciosas informaciones a las pesquisas del historiador Roberto Mendès Barbudo. Puede también consultarse F. de Paula Pérez Sindreu, «Variaciones en el valor de las monedas en el siglo XVIII para paliar la escasez de plata y evitar la salida de las monedas españolas al extranjero», Gaceta Numismática, 156 (2005), págs. 35-46.

LXXXII Títulos, «causa, razón, motivo o pretexto» (DRAE). 
mérito y de honor y que sois catorce hermanos», y otras particularidades que le sorprendieron. El duque le ha dado varias noticias de la nobleza de su casa, que él ignoraba, porque parece que tuvo comisión secreta de informarse de esto. En fin, todo prueba que se ha hecho conversación muy larga delante de los reyes sobre sus asuntos y que estos son de consecuencia. Por tanto, no te descuides en escribir a Vidal con el mayor empeño.

Tu Discurso sobre la historia pasará a Fita, como juez de la Imprenta Real, y éste me lo remitirá a censura: descuida. Del Abate nada sé porque no me escribe, ni quiero ir a casa de Melón a preguntar por su importante salud. Pásalo bien. Agur.

16 de octubre de 92.

Damón

\section{Carta XIV}

Madrid, principios de enero de 1793 (PG, X: 18-19)

Tu ministro plenipotenciario ${ }^{104}$ se presentó al último día del año a Monsegneur, cuando salía de comer, trayendo a la cola a Acuña, Llaguno, Cerdá, Sangro, Osuna, etc. ${ }^{105}$ «Muchos papeles trae Vm., Bernabéu.» «Señor, muchos y buenos.» Retíranse los próceres a un rincón de la sala y prosigue: «Señor, esta es la Dedicatoria ${ }^{106}$, que ha parecido bien a los inteligentes, y deseo que guste igualmente a vuestra excelencia. Aquí están las Antigüiedades ${ }^{107}$; estas son las Exequias $^{108}$, obra de ingenio, de la cual vuestra excelencia puede ser el censor,

104 Pérez de Guzmán anota entre paréntesis que se trata de Francisco Bernabéu.

105 Eugenio Llaguno y Amírola (1724-1799) era secretario del Consejo de Estado desde el primer día que Godoy había entrado en el gobierno, el 15 de noviembre de 1792, al igual que Pedro de Acuña Malvar, que fue nombrado secretario de Gracia y Justicia. Cfr. La PARRA, Manuel Godoy, págs. 152-157. Pablo Sangro y de Merode, príncipe de Castelfranco (1740-1815), llegó a España en tiempos de Carlos III; él y el duque de Osuna iban a distinguirse por su participación activa en la guerra contra Francia.

106 Como he dicho, esta primera versión del Discurso sobre la historia iba encabezada con una Dedicatoria a la reina María Luisa que, según anota F. López, se ha perdido, y sólo conocemos un borrador que se encuentra entre los papeles de Forner que conserva don Juan Grinda. Cfr. López, Juan Pablo Forner, pág. 509 , n. 36. Por tanto, no podemos saber la razón por la que «quedaron estupefactos» al percibir «la finura con que esta[ba] hilada» (Cfr. carta 11).

107 Alusión a una obra escrita por el padre de Forner, titulada Antigüedades de Mérida, metrópoli primitiva de la Lusitania, desde su formación en razón de colonia, hasta el reinado de los árabes, por el doctor Agustín Francisco Forner y Segarra, médico titular de dicha ciudad. Este trabajo quedó inédito hasta 1893, cuando lo publicó Tomás Romero de Castilla y Perozo. Cfr. M. A. Lama, «Sobre papeles manuscritos de Juan Pablo Forner», en J. Cañas Murillo y M. A. Lama (eds.), Juan Pablo Forner y su época (1776-1796), Mérida, Editora Regional de Extremadura, 1998, págs. 134-135.

108 Probablemente la obra más importante del escritor extremeño, Exequias de la lengua castellana, concebida en torno a 1783-1784, retocada en varias ocasiones y sólo ahora lista para ser publicada. Véase 
y que no perderá su tiempo en leerla. Es necesario que vaya a alguno imparcial a censura, porque aquí se critica a la mayor parte de los escritores del tiempo de Carlos III.» «Bien, ya la enviaré yo a quien no tendrá interés.» «Pero, señor, es menester que Forner venga a correr con estas impresiones.» «Bien está, yo veré esto y hablaremos.»

Esto es, en suma, lo que ha pasado. Bernabéu piensa estar con él dentro de seis u ocho días y concluir esto de tu venida, que es lo que por ahora importa, y no te escribirá hasta que sepa la respuesta. Ha insinuado Vicente Juliá (aquel músico que verías muchas veces en mi cuarto, ahora es secretario del duque ${ }^{109}$ ) que envíe las Antigüedades a Miguel de Manuel a censura y las Exequias a mí110.

Los asuntos de Bernabéu van también en el mejor estado, y espero que se quedará aquí bien empleado. Don Luis ha reído mucho con tu carta, a pesar de Cladera, que es su oráculo ${ }^{111}$ por culpa tuya y del abate y que habla muy mal de vosotros, por lo cual todo lo que en tu sátira decías contra Nifo y Escartín ${ }^{112}$, lo he convertido yo contra él, pues el pobre Nifo pidió cuartel a Bernabéu, alabó

la excelente edición crítica de J. Jurado en J. P. Forner, Exequias de la lengua castellana. Sátira menipea, Madrid, CSIC, 2000, págs. LVII-LXIV.

109 No he podido averiguar exactamente quién es este personaje. De él se conoce una traducción manuscrita conservada en AHN, Estado, 4818 (30), Viaje de España y Marruecos, Madrid, 1788. Cfr. AgullaR PIÑAL, Bibliografía, t. IV, pág. 774.

110 A pesar de las recomendaciones, la sátira de Forner no fue censurada por Estala. Primero llegó a manos del arzobispo e inquisidor general, Manuel Abad, que la devolvió sin examinarla alegando habérselo impedido sus obligaciones; después la vio el cardenal arzobispo de Toledo, Francisco Lorenzana, que emitió un informe en el que acusaba al autor de defender las ideas revolucionarias que se habían expandido desde Francia, sorprendente valoración de un texto que, como apunta F. López, es una defensa nacionalista y patriótica de los valores más castizos de España, aderezada con grandes dosis de erudición y de agresiva polémica. Godoy devolvió a Forner el manuscrito de las Exequias el 5 de marzo de 1795. Véase López, Juan Pablo Forner, págs. 572-603.

111 Que Cladera era un adulador ha sido demostrado por los historiadores: Emilio La Parra apunta que en 1794 dedicó a Manuel Godoy «un estudio sobre los descubrimientos españoles en América donde no fue parco en atribuirle gloriosa ascendencia, emparentándolo por línea paterna con los reyes de León Alfonso III, Fruela II y Ramiro II, así como con Fernando III, y por la materna con el primer rey de Portugal Alfonso Enríquez y con los descubridores Cabral, Vasco de Gama y Magallanes. Tales atribuciones hicieron fortuna y fueron repetidas por otros aduladores, como Tadeo Calomarde, quien hizo lo propio en un discurso pronunciado en 1800 en la Sociedad Aragonesa de Amigos del País, citando expresamente a Cladera». Cfr. La Parra, Manuel Godoy, pág. 59.

112 Forner se ensaña en las Exequias contra los periodistas en general y contra Francisco Mariano Nipho (1730-1803) y su yerno, Francisco Antonio Escartín, en particular. Primero los llama «especie de comerciantes de papel impreso», para después definirlos: «Llámanse escritores periódicos ciertos faramallistas que, incapaces de escribir por sí uno o más libros originales, se ocupan en publicar de cuatro en cuatro, de ocho en ocho, de quince en quince o de treinta en treinta días unos papelillos, atestados por lo común de vulgaridades y lugares comunes, destinados a ocupar el ocio y las conversaciones de un pueblo idiota, que cree no serlo. Estos papelillos pudieran ser en gran manera útiles, pero en el estado actual no son más que menstruaciones literarias, superfluidad asquerosa; pero de tan maligna calidad que, en vez de contribuir a la salud, son indicio de una dolencia incorregible». Y sigue ensartando crudas palabras que Estala «volvería» contra Cladera, haciendo reír a todos. Cfr. Forner, Exequias de la lengua castellana, págs. 76-79 o págs. 138-139. 
mucho la sátira y todo lo demás; fuera de que no es tan facineroso como el tal Claderilla. Jove te conserve.

Pedro de Estala

\section{Carta XV}

Madrid, primavera de 1793 (PG, XI: 19-20)

Tú dirás, y casi casi te sobre la razón, que yo soy un poltrón ${ }^{\mathrm{LXXXIII}}$ de primera clase; pero, qué quieres, tanto he dado en tratar con filósofos que yo también me voy afilosofando ${ }^{113}$. Pero, hablando seriamente, has de saber que jamás he estado más ocupado que ahora: in $_{\text {primis }}{ }^{\text {LXXXIV }}$ estoy acabando de imprimir mi traducción del Edipo tirano ${ }^{114}$, al cual he puesto por morrión mi Discurso sobre la tragedia. Ya ves que para que salga todo esto como debe habrá sido preciso limar y lamer infinito. Item, he estado lamiendo y limando el otro Discurso sobre la comedia ${ }^{115}$ para ponérselo por gorro al Pluto ${ }^{116}$, que voy a dar al público si el Edipo me deja alguna ganancia, que es el único objeto de mis lucubraciones. Item, he estado anotando, prologando, comentando (arrige aures ${ }^{\mathrm{LXXXV}}$ ) un ma-

LXXXIII Poltrón, del italiano poltrone, «flojo, perezoso, haragán, enemigo del trabajo» (DRAE).

113 Juega aquí Estala con las dos acepciones de la palabra filósofo que circulaban por estas fechas. Por un lado, se consideraba que eran verdaderos filósofos aquellos que buscaban, mediante el análisis libre de prejuicios y el estudio detenido, los principios naturales que explican la idiosincrasia de las cosas. El problema es que, a finales del siglo XVIII, el llamado espíritu filosófico o de análisis va a impregnar todas las disciplinas, tanto las estrictamente científicas como las artísticas, de manera que se inaugura una nueva forma de escribir, menos académica, más intuitiva, próxima al estilo ensayístico de los philosophes franceses (Voltaire, Diderot, etc.). Los humanistas eruditos, como Forner, entre otros, criticarán a estos filósofos de nuevo cuño por superficiales y faltos de verdadero estudio, escritores a la violeta, pedantes de café, que beben su saber de los periódicos y de los compendios. Cfr. J. Álvarez Barrientos, Los hombres de letras en la España del siglo XVIII: apóstoles y arribistas, Madrid, Castalia, 2006, pág. 55 y ss.; y M. a Elena Arenas Cruz, «Una crítica irónica al método ensayístico aplicado a la historia: el Libro de moda en la feria (1795)», en La época de Carlos IV (1788-1808). Actas del IV Congreso Internacional de la Sociedad Española de Estudios del Siglo XVIII, ed. de Elena de Lorenzo Álvarez, Oviedo, IFESXVIII-Sociedad Estatal de Conmemoraciones Culturales, 2009, págs. 209-218.

LXXXIV In primis, «en primer lugar».

114 Se trata de Edipo tirano, tragedia de Sófocles, traducida del griego en verso castellano, con un discurso preliminar sobre la tragedia antigua y moderna, por don Pedro Estala, presbítero, Madrid, Imprenta de Sancha, 1793. La versión de Estala vio la luz antes del 21 de junio de 1793, pues en esta fecha Miguel de Manuel envió un ejemplar de la obra a Campomanes. Cfr. J. Simón DíAz, «Los Reales Estudios de San Isidro: nuevas noticias», Anales del Instituto de Estudios Madrileños, IX (1973), págs. 3-5.

115 Ambos discursos, que aparecen como prólogos de las dos citadas traducciones, habían sido leídos por Estala en la cátedra de Historia Literaria de los Reales Estudios de San Isidro, en los ejercicios públicos celebrados en 1792.

116 Estala había traducido la obra de Sófocles y ésta de Aristófanes en su juventud. A pesar de que no estaba muy satisfecho con esta última, tal como le dirá a Humboldt (cfr. Diario de viaje a España, Madrid, Cátedra, 1998, p. 121), la imprimirá al año siguiente.

LXXXv Arrige aures, "aguza los oídos». 
nuscrito $^{\mathrm{LXXXVI}}$ intitulado Juicio de artes y ciencias por el licenciado Navarrete, canónigo etc., el cual manuscrito he encontrado entre los que manejo ${ }^{117}$.

¿Conoces esta obrita? ¿No? Pues sábete que es la misma, mismísima República literaria, atribuida falsamente a Saavedra, pero tan distinta, que sólo por el principio y el fin se conoce que es la misma. El falsificador, que yo creo fue el canónigo Salinas, todo lo trastornó: lo que quitaba de en medio, lo ponía al principio; lo del principio, al fin, mezclando digresiones, reflexiones importunas y cosas que no pensó el autor, y omitiendo lo más esencial y excelente de la obra. En fin, ya la verás impresa y te quedarás estupefacto y vencido de la superchería del falsificador y corruptor de esta preciosa obrita ${ }^{118}$. Estas ocupaciones, añadidas a las ordinarias, me han ocupado de tal suerte que he ido dilatando responderte de un correo a otro. Ahora voy a tus dubios ${ }^{\text {LXXXVII. }}$

El beneficio que han dado a Condado ${ }^{119}$, aunque es en Montoro, es distinto del de nuestro Abate, el cual subsiste en Londres y no sabemos de él ya hace tiempo.

Tus mamotretos sin duda han quedado sepultados y no sabemos su paradero; cuando venga la corte procuraré averiguar por Llaguno lo que ha sido de

LXXXVI manuscrito. He desarrollado la abreviatura M. S. PG, 19.

117 El manuscrito aludido pertenecía a una miscelánea de diversos textos coleccionados por el jesuita Antonio Arana (1588-1650), entre los que había un opúsculo titulado Juicio de artes y ciencias, con una nota de Arana en la que designaba como autor a Pedro Fernández Navarrete, canónigo de Santiago y secretario de la reina doña Margarita (entre cuyas obras se recuerda la titulada Restauración de monarquías, Madrid, 1626).

118 Para entender las alusiones de Estala hay que recordar que Diego Saavedra Fajardo (1584-1648) había dejado la República literaria inédita al morir. De la obra se conocían dos versiones: una primera redacción realizada en Italia alrededor de 1613 y que circuló manuscrita y anónima, y otra posterior, que contendría las correcciones hechas por Saavedra alrededor de 1640, tan importantes que casi suponen una refundición o nueva versión del texto. Cfr. A. BLECuA, «Las Repúblicas literarias y Saavedra Fajardo», El Crotalón, I, 1984, págs. 67-93. Esta segunda versión vio la luz por primera vez en 1655, con el título de Juicio de artes y ciencias, bajo el nombre de un suplantador, Claudio Antonio de Cabrera (aunque, como he dicho antes, en el manuscrito de Arana, éste adjudica esta versión al canónigo Navarrete). Será en 1670 cuando, con el título de República literaria y ya bajo el nombre de Saavedra Fajardo, se publique en Alcalá a instancias de José Salinas, con un prólogo al lector del doctor Francisco Ignacio de Porres. De esta edición ampliada editada por Salinas y Porres derivan en general las ediciones que en el siglo XVIII se hicieron de la República literaria, obra considerada por los ilustrados como modelo de prosa castellana y, por tanto, ejemplo digno de imitación. Sin embargo, para Estala, ninguna de las dos versiones es de Saavedra, ni la primera, el texto sencillo y depurado que él ahora pretende editar, ni la conocida por todos, que es fruto de un adicionador, pues, según él, está llena de errores y despropósitos, tanto formales como de contenido.

LXxxvII Dubios, «dudas».

119 El presbítero Manuel Joaquín Condado era profesor de derecho natural en los Reales Estudios de San Isidro durante el curso 1792-1793, fecha en que recibe un beneficio eclesiástico en Montoro. Cfr. Simón DíAz, Historia del colegio imperial, pág. 47. Un acercamiento al trabajo de este personaje puede verse en «Del derecho natural a la ciencia política: Manuel Joaquín Condado y la cátedra de Derecho Natural y de Gentes de los Reales Estudios de San Isidro (1770-1794)», en AA. VV., Estudios de derecho constitucional y ciencia política. Homenaje al profesor Rodrigo Fernández-Carvajal, Murcia, Universidad de Murcia, 1997, págs. 1187-1206. 
ellos. Ya sabrás que el bueno de Bernabéu está en su lugar y, por consiguiente, tus asuntos y los del Abate quedan suspensos, fuera de que la guerra con los malditos gabachos da tanto que hacer al ministerio que en ninguna otra cosa pueden pensar ${ }^{120}$. Yo tenía una pretensión con el Frío sobre cierta empresa lucrativa y nada me ha contestado, ni lo espero. Si tú hubieras venido, quizá hubieras logrado algo aquí, pues en este tiempo han vacado ${ }^{\mathrm{LXXVIII}}$ cosas que te hubieran acomodado mucho. Meléndez lo ha acertado, que se ha encajado aquí y tiene sus cosas en muy buen estado y creo que conseguirá quedarse bien empleado ${ }^{121}$. No seas bobo: insta por venir y déjate de pretensiones por cartas, que nunca adelantarás nada.

Ya te enviaré mis opúsculos cuando estén acabados. Fra tanto, vegeta ${ }^{\mathrm{LXXXIX}}$. Adiós.

Damón

\section{Carta XVI}

Madrid, junio de 1793 (PG, IX: 17-18)

Porque no creas que me he vuelto Huerta ${ }^{122}$, te envío el ejemplar de capillas ${ }^{\mathrm{XC}}$ de mi engendro ${ }^{123}$. Por él verás que no estoy tan mal con mi reputación literaria que me empeño en defender disparates. No espero honra ni provecho de una obra que me ha costado harto trabajo para lo que mi poltronería acostum-

$120 \quad$ La guerra contra la Convención francesa, que amenazaba con acantonar cien mil franceses al otro lado de la frontera, se declara a finales de marzo de 1793; terminará en agosto de 1795, con la firma de la Paz de Basilea.

LXXXVIII Vacar, «quedar un empleo, cargo o dignidad sin persona que lo desempeñe o posea» (DRAE).

121 Según cuenta Manuel José Quintana, al poco tiempo de ser nombrado oidor de la Chancillería de Valladolid en 1791, Meléndez fue comisionado «por el Consejo de Castilla para la reunión de cinco hospitales en Ávila de los Caballeros», un encargo que le resultó enormemente embarazoso, le costó muchas fatigas y dos enfermedades. Por tanto, en 1793 viaja a Madrid con la pretensión de buscar acomodo en la capital del reino, pero, aunque Estala se muestra aquí optimista, la verdad es que Meléndez hubo de volverse a Valladolid, donde permaneció hasta 1797, fecha en que es nombrado fiscal de la Sala de Alcaldes de Casa y Corte de Zaragoza. Cfr. M. J. Quintana, «Noticia histórica y literaria de Meléndez», cit. por Astorgano Abajo, Don Juan Meléndez Valdés, pág. 402.

LXXXIX Fra tanto, vegeta, «mientras tanto, vegeta», en sentido figurado, «disfruta voluntariamente de una vida tranquila, exenta de trabajo y cuidados» (DRAE).

122 Alusión a Vicente García de la Huerta, que, por metonimia, sirve aquí para significar «absurdo defensor de disparates». Este poeta y dramaturgo había sido objeto de burlas y chanzas por parte de Estala y sus amigos a propósito de su particular antología del Theatro hespañol (Madrid, Imprenta Real, 1785) y del prólogo que la acompañaba, donde defendía una ideología ultra conservadora, opuesta a cualquier renovación. Cfr. J. A. Ríos Carratalá, Vicente García de la Huerta (1734-1787), Badajoz, Diputación Provincial de Badajoz, 1987.

XC Capilla, «pliego que se entrega suelto durante la impresión de una obra» (DRAE).

123 Estala envía a su amigo un ejemplar de su traducción del Edipo tirano, de Sófocles. 
bra, siendo ésta la primera cosa de que he hecho borrador. Pero, en fin, no daré con ella ganancia a potreros ${ }^{124}$ ni perderé dinero aunque no se venda, pues se imprime de cuenta de la Biblioteca, con la ganancia para mí. Ya me escribirás lo que te parezca la tal obrilla.

Sobre la República literaria no pases pena de que yo me comprometa: refiero la historia literaria de esta obrita, lo que hallo en mi manuscrito, pero sin afirmar que sea de Navarrete. Lo que afirmo y pruebo es que se escribió a fines del siglo XVI; que su autor hizo una obra excelente y que el falsificador, sea quien fuere, la corrompió en extremo, añadiendo cosas importunas y muy ajenas del objeto que su autor se propuso. Como lo expreso ${ }^{\mathrm{XCI}}$ en un prologuito muy gracioso, mezcló mil disparates y pedanterías y omitió pedazos muy considerables y excelentes. Solamente los pleitos que sentencian los jueces de la República (que no los saca del infierno como el necio zurcidor de majaderías) valen más que todas las miserias que él añade ${ }^{125}$. Probado todo esto y afirmando que semejante superchería y tan enormes disparates son muy ajenos de un hombrón como Saavedra, dejo la cosa indecisa. Y si luego me salen con que hay un manuscrito de propia mano de Saavedra en que afirma que es suya la obra, pro les haga; yo no se lo disputaré en cuanto a las adiciones, pero que el estilo del manuscrito que yo voy a imprimir se parezca ni aun remotamente al de Saavedra, ni probar que sea obra original de éste, eso es lo que no se puede probar con manuscrito, sino refutando mis razones, y esto es algo difícil ${ }^{126}$. Basta de erudición.

De Bernabéu nada sé; menos de tus manuscritos. Ten paciencia y haz que tu cara mitad los encomiende a san Antonio, abogado de las cosas perdidas. Adiós. Damón

124 Puede ser una alusión irónica al cirujano Ramón Fernández, financiador de la Colección de poetas castellanos y principal beneficiario del producto de su venta, pues, en su uso familiar, se llama potrero al «cirujano que con particularidad se dedica a curar potras, es decir, hernias en el escroto» (DRAE).

XCI expreso [corrección mía] expresa PG, 17.

125 Se refiere Estala al episodio con el que termina la obra, que en la versión revisada por Saavedra está mucho más reducido que en la primitiva, la que ahora él está preparando. Puede leerse a pie de página en alguna de las ediciones modernas, por ejemplo D. SaAvedra Fajardo, República literaria, ed. de V. García de Diego [1942], Madrid, Espasa Calpe, 1973, pág. 124 y ss.

126 Efectivamente, en tiempos de Estala ya se conocía la existencia de un manuscrito de la segunda redacción de la República literaria, con correcciones autógrafas y la firma de Saavedra Fajardo. Hoy está demostrado de manera incuestionable que el propio Saavedra refundió la República literaria a partir de una copia ya defectuosa de la versión primitiva, corrigió errores de bulto y dejó pasar otros de índole cultural, a la vez que remozó el estilo y la ideología para que no resultara una antigualla histórica a los lectores de mediados del siglo XVII. Sobre las controversias que ha suscitado entre los filólogos esta cuestión, véase A. BLECUA: «Las Repúblicas literarias»; y «Un nuevo manuscrito de la República literaria», Edad de Oro, III (1984), págs. 11-27. También J. Dowling, «Saavedra Fajardo’s República literaria. The Bibliographical History of a Little Masterpiece (part one)», Revista Hispanófila, 67 (1979), págs. 7-38; 68 (1980), págs. 11-27; y 69 (1980), págs. 24-44; y mi pequeño estudio en el libro Pedro Estala, págs. 197-213. 


\section{Carta XVII}

Madrid, julio de 1793 (PG, XXI: 34-36)

Me alegro te haya gustado mi diatriba teatral y los repasos que haces sobre la brevedad con que toco algunos puntos; son sólidos, pero no da lugar a más la poca paciencia de nuestros lectores, que en el día nada quieren leer sino noticias o majaderías. No podrás creer cuán mudado está este teatro; te aseguro puedes alegrarte de estar entre andaluces, tous andaluzes que ellos son ${ }^{\mathrm{XCII}}$, por no estar en Madrid en este tiempo. Cuando uno encuentra $a^{\mathrm{XCIII}}$ otro en la calle o paseo, mal que le pese, le ha de detener media hora por lo menos con la pregunta acostumbrada: ¿qué tenemos de noticias? Y no hay excusarse con decir «no sé nada», pues, vellis nollis ${ }^{\mathrm{XCIV}}$, te han de encajar un centenar de patrañas absurdas y ridículas. Yo me he cerrado en no hablar de gabachos en pro ni en contra, pero ni por ésas me puedo escapar de la maza de los noticieros. Ahora, figúrate tú qué caso harán semejantes brutos de Edipos, ni de discursos, ni de poesías, ni de cosa que no huela a política (de la que ahora se usa) o a guerras ${ }^{127}$. Si ahora te hallases aquí, a pesar de tu manía de escriborrotear, quemarías todos tus mamotretos y libros y te echarías a vegetar, como yo hago, o a charlatán político, como todos nuestros sabios.

A propósito de sabios, sabe que el sapientísimo censor ${ }^{128}$, cansado quizá de

XCII Parece una frase hecha cuyo origen y sentido exacto Forner debía conocer, pero que yo no he podido precisar.

XCIII encuentra a [corrección mía] encuentra o PG, 35.

xCIV Vellis nollis, «quieras o no quieras».

127 Estala pasa de puntillas y como si no le afectaran por encima de las alarmantes noticias que venían de Francia. Una vez caído el partido burgués de los girondinos, toman el poder los radicales jacobinos, que, forzados por las masas de sans-culottes, exasperadas por la carestía y la escasez, imponen las grandes medidas revolucionarias del Comité de Salvación Pública, que llevó a la guillotina a cientos de personas en el otoño de 1793. Al mismo tiempo, la guerra civil y la guerra con el extranjero en diversos frentes (Austria, Bélgica, Prusia, España, Inglaterra...) amenazaban la integridad nacional francesa. Pero, fiel a su propia advertencia, Estala no cruza con Forner ni una sola opinión política, consciente de que el poder, temeroso de que se repitan los episodios del país vecino, se ha aliado con la Inquisición, no con la Ilustración. Años después, el helenista manchego aludirá desde El Imparcial a esta ola de oscurantismo y amenazas: «Se declaró una atroz persecución contra las luces; se excitó a la Inquisición a que castigase como crimen de religión lesa los esfuerzos para ahuyentar la barbarie; los que se distinguían por sus conocimientos fueron perseguidos o mirados como sospechosos» (pág. 104). Sobre la ideología política de Estala, puede verse mi trabajo «La esperanza dolorida de los afrancesados: El Imparcial de Pedro Estala» en España 1808-1814. De súbditos a ciudadanos, t. I, vol. II, Madrid, Junta de Comunidades de Castilla-La Mancha y Sociedad Estatal de Conmemoraciones Culturales, 2008, págs. 251-266.

${ }_{128}$ Es muy probable que se trate de Santos Díez González (1743-1804), que, tras ocupar desde junio de 1789 la plaza de censor interino de comedias (en sustitución del fallecido Francisco López de Ayala), es designado definitivamente para este cargo el 8 de diciembre de 1791, con un sueldo de 6000 reales y entrada franca a los teatros de la Cruz y del Príncipe. Desempeñará esta actividad hasta su muerte en 1804. Cfr. C. 
ser filósofo, o presumiendo hacer agua por otra parte, es acérrimo enemigo de los franceses, esparce noticias forjadas en su mollera de derrotas continuas y predica todo lo contrario de lo que predicaba un año antes: esta sí que es filosofía. Pero dejemos esto, que aún tratado así fastidia.

Tu poemario ${ }^{\mathrm{XCV}}$ me ha agradado en extremo; lo mismo le ha parecido a Batilo y ambos extrañamos que todavía estés para estas bagatelas, cuando únicamente debías pensar en algún infolio sobre economía política o sobre re bellica $^{\mathrm{XCVI}}$. El pobre Batilo, después de estar aquí cinco o seis meses lleno de grandes esperanzas, comiendo a mesas de altos señores ${ }^{\mathrm{XCVII}}$, se habrá de ir pronto, rabo entre piernas, sin conseguir nada y sin la menor esperanza. Bernabéu ha vuelto de su lugar un doble más gordo de lo que fue ${ }^{129}$, y sin saber qué hacer ni qué partido tomar. De tus obras no hay la menor noticia, y lo peor es que no las volverás a ver de tus ojos ${ }^{130}$ a no ser por un milagro, como el que ha sido necesario para recoger yo algunos mamotretos que había presentado a Alba-florita ${ }^{131}$, entre los cuales he hallado los cinco libros de Plutarco De placitis philosophorum, cuya traducción al cabo de diez años me ha parecido bien y la voy a imprimir ${ }^{132}$, se entiende sin exponer mi dinero, porque no estamos en tiempo de arriesgarlo en obras de esta clase. Se está ya imprimiendo la nueva República literaria, que verás bien pronto ${ }^{133}$. Asimismo voy a imprimir el Pluto de Aristófanes con otro

Cambronero, «Un censor de comedias: apuntes para la historia del teatro», Revista Contemporánea (1896), págs. 150-159, 292-300, 378-385 y 492-502; y A. V. Ebersole, Santos Díez González, censor, Valencia, AlbatrosHispanófila, 1982.

XCV poemario [corrección mía] poemacio $\mathrm{PG}, 35$.

XCVI Re bellica, «la guerra».

XCVII La expresión propiamente dicha es «comer a manteles» es decir, comer en mesas cubiertas de manteles, que es lo natural de los señores, pues todos los demás comían en mesas sin manteles.

129 Era tan gordo Bernabéu que es el tema central de la sátira burlesca que cariñosamente le compone su amigo Forner para presentársela al Príncipe de la Paz como salvoconducto para que este le otorgue un empleo en el que no tenga que moverse mucho, pues el caballo no soporta su peso. Cfr. Cueto, Poetas líricos del siglo XVIII, págs. 328-329.

130 Repárese en el pleonasmo burlesco, de ecos medievales.

131 Apelativo jocoso aplicado al conde de Floridablanca, primer secretario de Estado de 1777 a 1792 , mecenas y protector de Forner y Moratín y al que Estala le debió entregar también sus trabajos con el fin de obtener igualmente algún beneficio.

${ }^{132}$ Por lo que he podido averiguar, esta obra no llegó a imprimirse. El manuscrito se encuentra en la Biblioteca Menéndez Pelayo de Santander (ms. 248) y lleva el siguiente título: Los cinco libros sobre las opiniones de los filósofos, de Plutarco. Traducido del griego e ilustrado por D. Pedro Estala, presbítero; está fechado en Madrid, el 14 de septiembre de 1793. Esta fecha no indica el momento en que nuestro helenista realiza la traducción, sino cuando la revisa para imprimirla, pues, como él mismo apunta, se trata de un trabajo de juventud, realizado al menos hace diez años.

133 La edición que Estala preparó de la primitiva versión de la República literaria llevaba el siguiente título: Discurso curioso, agudo y erudito acerca de la multitud de libros que cada día se publican; y juicio de los autores en todas facultades, así modernos como antiguos: escribióle en meditación retirada nacida de la continua lición y estudio de todo género de escritores, $N$. de N., secretario de su Majestad. Vio la luz de manera anónima en agosto de 1793, en el sexto tomo de una publicación periódica atribuida a Isidoro Bosarte y cuyo 
discurso sobre la comedia, pues teniendo ya hecho este trabajo y no costándome nada la impresión, quiero echarlos a volar a salga lo que saliere ${ }^{134}$.

Sabe que se ha impreso en Salamanca el primer tomo de las Poesías de Iglesias, que contiene las picarescas: epigramas y parodias. Se está imprimiendo el segundo, que no sé lo que contendrá ${ }^{135}$. Mucha falta le ha hecho al buen Arcadio que alguno de nosotros no haya andado en esto, pues aunque la impresión es bonita, ha habido poco tino en la elección y corrección de las piezas ${ }^{136}$.

El Abatucho prosigue en Londres ${ }^{137}$ y me hace al favor de no escribirme, lo que le estimo en 12 reales cada correo, que yo también sé estimar a las gentes según el producto que dan o el gasto que excusan, tanti viri exemplo ${ }^{\mathrm{XCVIII}}$.

Pásalo bien y ama a tu buen

Damón.

título era Gabinete de lectura española (Madrid, Imprenta de Sancha, s. a.), aunque hoy sabemos que se trataba de un proyecto concebido y dirigido por Miguel de Manuel, bibliotecario primero de los Reales Estudios de San Isidro (AHN, Estado, 3242, 7).

134 Tardó casi un año en imprimirse El Pluto. Comedia de Aristófanes traducida del griego en verso castellano, con un discurso preliminar sobre la comedia antigua y moderna. Por D. Pedro Estala, presbítero, Madrid, Imprenta de Sancha, 1794. Fue objeto de una elogiosa reseña en el Memorial Literario de octubre de ese año (págs. 47-53).

135 Es la primera edición de las poesías de Iglesias, cuyos manuscritos había legado a su cuñado y librero, que las saca en dos volúmenes: Poesías póstumas de D. José Iglesias de la Casa, presbítero, Salamanca, Francisco de Tójar, 1793. En su alusión se equivoca Estala, pues el primer tomo contenía las poesías serias, mientras que las jocosas aparecen en el segundo. La edición fue reseñada en el Memorial Literario, II, 1794, págs. 185-191.

136 Esta edición iba encabezada por una carta prólogo de Manuel José Quintana, que firmó con una A, tras la que se escondía Anfriso, su seudónimo poético. Según revela Bartolomé José Gallardo en su Correspondencia, en la edición participaron también Antonio Calama, Núñez y Munárriz. Cfr. A. Derozier, «Introducción» a M. J. Quintana, Poesías completas, Madrid, Castalia, 1969, pág. 24. La carta fue muy criticada porque en ella se negaba al poeta Villegas todas las prendas que la tradición le había otorgado; además, los jóvenes editores adjudicaron a Iglesias traducciones y composiciones que no eran suyas, lo que fue desvelado pronto en la prensa de Salamanca y de Madrid, para oprobio de sus amigos.

137 Gracias a una ayuda de 30000 reales que Godoy le concede en julio, Moratín podrá finalmente salir de Inglaterra el 5 de agosto de 1793. Se traslada a Italia, donde permanecerá tres años visitando las ciudades más famosas. Desde allí seguirá luchando por conseguir un puesto remunerado y tranquilo, como, por ejemplo, el de director de la Biblioteca Real o el de la de los Reales Estudios de San Isidro; con esta petición le escribe al duque de la Alcudia el 28 de septiembre de 1793: «Bayer está viejo y don Miguel de Manuel es, en mi opinión, un sujeto de un mérito tan distinguido que no es creíble permanezca largo tiempo arrinconado entre los libros de San Isidro. Cualquiera de estas dos plazas (y en particular la primera) sería conveniente para mí». Cfr. «Carta a Godoy», ed. por Danvila en el Boletín de la Academia de la Historia, XXXVI (1900), pág. 443, y cit. por Simón DíAz, Historia del colegio imperial, pág. 339. Es evidente que, puestos a elegir, don Leandro prefiriera no tener como subordinado a su amigo Estala en la Biblioteca de los Reales Estudios, a la que este se había visto «relegado» porque el dramaturgo no había buscado los apoyos oportunos para su candidatura a la cátedra de Poética en dicha institución.

хCVIII Tanti viri exemplo, «varones tan notables sirven de ejemplo». 


\section{Carta XVIII}

Madrid, octubre o noviembre de 1794 (PG, XVII: 27-28)

Hombre, yo no sé en qué piensas que no has tomado ya la posta y te has encajado aquí. Bernabéu me ha dicho que te ha escrito sobre esto y te ha hecho relación de los elogios que de ti ha hecho el duque. Si pierdes esta ocasión no te quejes luego de que te dejen podrir ${ }^{\mathrm{XCIX}}$ en esa fiscalía hasta que el diablo te lleve. No sólo adelantarás más tus negocios con una conversación que con mil cartas y librotes, sino que el mismo duque creo te estimará le des luces en el estado actual de las cosas, tan críticas, y es ${ }^{\mathrm{C}}$ que no tiene a su lado más que Urquijos ${ }^{138}$ y otros de esta ralea. Por ende, puedes hacer tu negocio, ayudar a tu bienhechor y servir al Estado en una ocasión tan urgente cual jamás se ha visto. Pero yo estoy persuadido que no vendrás y después harás más lamentaciones que Jeremías quejándote ${ }^{\mathrm{CI}}$ de hombres y dioses y echándoles la culpa de tu descuido.

Cuando vengas, si es que vienes, no conocerás este mundillo. Pasó el siglo de la literatura. Yo he hecho un ensayo de esta verdad en el Diario poniendo una carta a favor del teatro y después impugnándome a mí mismo: la misma sensación ha hecho el pro que el contra ${ }^{139}$. Todos se han metido de hoz y de $\operatorname{coz}^{\mathrm{CII}}$ a políticos; todo es hablar de noticias, de reformas, de arbitrios, etc. Vente, pues, con literaturas a esta gentecilla y ya no entenderán tu lenguaje. Hasta los mozos de esquina compran la Gaceta en las tabernas, y en los altos estrados, junto a Mariblanca $^{140}$ y en el café, no se oye más que batallas, revoluciones, Convención, representación nacional, libertad, igualdad. Hasta las... ${ }^{\text {IIII }}$ te preguntan

xcIx Podrir, forma arcaica de pudrir.

C es [corrección mía] en PG, 27.

138 Mariano Luis de Urquijo (1768-1817) era uno de los oficiales de la Secretaría de Estado nombrado por Aranda (1792), pero siguió formando parte del gabinete de gobierno con el que empezó a trabajar Godoy. Será destituido en diciembre de 1794. No obstante, a la caída de Francisco de Saavedra llegará a ocupar el cargo de primer secretario de Estado (desde 1798 hasta 1800), durante cuyo desempeño apoyó el viaje científico de Humboldt por la América española y redujo muchos de los privilegios de la Inquisición. Retomaría su actividad política con José I, haciendo suya la causa afrancesada, como Estala.

CI quejándote [corrección mía] quejándose PG, 27.

139 Se refiere a la carta firmada por Fabio Oretano en el Diario de Madrid el 2 de octubre de 1794, y a la respuesta inserta los días 4 y 6 de dicho mes, anónima pero cuyo autor dice que ha negado la tesis del influjo del teatro en las costumbres en su prólogo «a la traducción castellana del Pluto de Aristófanes». Ambas son, por tanto, del propio Estala; la respuesta puede leerse en mi edición Estala Ribera, Prefacios y artículos de crítica literaria, págs. 303-308.

CII Meterse de hoz y coz en algo es implicarse en ello por entero y de forma absoluta.

140 Era el nombre por el que se conocía la estatua de Venus que adornaba la antigua fuente que había en la Puerta del Sol.

CIII Hasta las... PG, 28. Hasta las... (mujeres perdidas) C. Mantengo la pudorosa censura de Pérez de Guzmán. 
por Robespierre y Barreré ${ }^{141}$ y es preciso llevar una buena dosis de patrañas gacetales para complacer a la moza que se corteja. ¿Crees recargado este retrato? Pues ven acá y verás lo que es bueno.

Los cómicos están esperando con ansia la copia de tu comedia según se representó en Cádiz ${ }^{142}$. Yo he examinado muy despacio el ejemplar que me dio Vinagrillo y me ha gustado más que nunca. Solamente he corregido los defectos del copiante y tres pasajes en que salían diciendo «yo lo he oído todo». Este medio usado por tres veces me ha parecido mal, porque denota pobreza de recursos cómicos; lo he dejado en un solo pasaje en que hace buen efecto y, en los otros dos lo he corregido con mucha facilidad, sin mudar más que un verso y sin perjuicio del enredo. Pero no hacemos nada con esto si no envías la copia de Cádiz, y sería mejor que tú mismo la trajeses y asistieses a los ensayos. En fin, tú harás lo que quieras, que siempre será lo peor para ti. Entretanto, yo vegeto, y cuando vengas

Me tamen et nitidum, et curata cute revises

ut videre possis, Epicuri de grege porcum ${ }^{143}$.

Adiós.

Damón

141 Bertrand Barreré de Vieuzac (1755-1841) fue elegido presidente de la Convención en 1792 y posteriormente miembro del Comité de Salvación Pública (7 de abril de 1793). Abandonó a Robespièrre cuando éste fue ejecutado con todos los suyos el 27 de julio de 1794; deportado al Poitou en 1795, se dedicó al periodismo y a publicar obras literarias y políticas.

142 La comedia de Forner titulada El Filósofo enamorado había sido estrenada en Cádiz en 1792. De nuevo será representada en esta ciudad los días 28 y 29 de abril de 1796, suscitándose una polémica similar a la que se produjo en Madrid y que ha sido estudiada por B. SÁnchEz HitA, «Teatro y diversiones públicas del Cádiz de finales del xviII: la polémica en torno a la representación de El Filósofo enamorado de Juan Pablo Forner», en La época de Carlos IV (1788-1808), págs. 1043-1055.

143 Se trata de una versión adaptada o manipulada de los últimos versos de la Epístola 4 de Horacio, aquellos que dicen: «Me pinguem et nitidum bene curata cute vises, / cum ridere voles, Epicuri de grege porcum» (I, 4, vv. 15-16), traducidos por Horacio Silvestre así: «Ven a verme a mí, gordo y lustroso, de cuidado cutis, lechón de la grey de Epicuro, cuando desees pasar un buen rato». Cfr. Horacio, Sátiras. Epístolas. Arte poética, págs. 372-373. En cambio, la versión de Estala puede traducirse: «A pesar de todo, me vuelves a ver no sólo cebado, sino además con la piel curtida, de modo que puedes ver a un cerdo de la piara de Epicuro». Debo esta traducción a la amabilidad de la profesora María José Dacosta. 


\section{Carta XIX}

Madrid, febrero o marzo de 1795 (PG, I: 5-8) ${ }^{144}$

Hombre, yo tenía dispuesta una larga epístola para enviártela sobre el suceso $^{\text {CIV }}$ del Filósofo, que ha excedido a mis esperanzas, aunque siempre creí que agradaría; pero de un día a otro lo he ido dilatando y ha sido precisa tu lavativa ${ }^{\mathrm{CV}}$ para hacérmela echar del cuerpo.

La comedia ha agradado infinito, como lo indican las entradas, que han ido subiendo de día en día, su duración por doce o trece días, y haberse dejado con más de cinco mil reales. Este es un argumento fuerte del mérito de una comedia que ni tiene batallas, ni desafíos, ni es de mágica o de maquinaria, como las ha bautizado nuevamente tu amigo don $\operatorname{Santos}^{145}$, a quien no ha agradado el Filósofo, prueba evidente de su bondad. La han ejecutado perfectamente los tres o cuatro que se sujetaron a mis advertencias, como Querol, la Polonia, la Porta y ${ }^{\mathrm{CVI}}$ Cubas; pero los padres maestros, García y la Rita, que nada quisieron hacer en el ensayo, lo han hecho muy fríamente. Debes dar las gracias a Querol, porque ha echado el resto ${ }^{146}$.

Entran ahora mis reparos. El esconderse la moza con Fernando en el acto primero hace muy mal efecto. El pueblo gruñó un rato cuando lo vio la primera vez, y temí una desgracia; después, en las demás representaciones siempre noté la misma murmuración. Por otra parte, aquel encierro no produce todo su efecto, y estos medios no se deben emplear sino para producirlo grande. Si la precipitación con que estos diablos de cómicos dispusieron la cosa no me hubiera

144 Aunque Cueto indica que esta carta es posterior a 1796, sin duda fue redactada mucho antes, en torno a febrero o marzo de 1795. La obra de Forner se representó en el Teatro de la Cruz el 28 de enero de 1795.

CIV Suceso, «éxito, resultado, término de un negocio» (DRAE).

CV Lavativa, sinónimo de enema, «medicamento líquido que se introduce en el cuerpo por el ano con instrumento adecuado para impelerlo, y sirve por lo común para limpiar y descargar el vientre» (DRAE).

145 Santos Díez González habla de «comedias de maquinaria» en sus Instituciones poéticas, Madrid, Benito Cano, 1793, págs. 135-136.

CVI $y$ PG, 6. Omitido en C.

146 Son éstos los principales actores de la Compañía de Eusebio Ribera: la hermosa y desenfadada Rita Luna, dama primera, Polonia Rochel, «la graciosa más notable, o al menos la más celebrada de las cómicas del siglo XVIII», Manuel García Parra, el primer galán, Mariano Querol, «gracioso de renombre y único en los papeles de figurón», Félix Cubas y Gabriela Porta. Cfr. Cotarelo y Mori, Isidoro Maiquez y el teatro de su tiempo, Madrid, Imprenta Perales y Martínez, 1902, pág. 25 y ss. Si a Estala no le había gustado la actuación de Rita Luna, no pensaba así el corresponsal anónimo que escribe a Forner a los pocos días de la representación: «Sin embargo que el pobre Torre no ha hecho la comedia por haber fallecido el sábado anterior, no ha dejado de darla su valor Luna. Todos generalmente la han ejecutado perfectamente. Cubas, Querol, Polonia, Rita, la Gabriela, la Porta y Manuel, todos han puesto sus conatos para el mayor lucimiento. Son acreedores a que envíe Vm. una carta para leérsela en el vestuario». Cfr. CueTo, «Bosquejo histórico-crítico», pág. CXLIII. 
impedido mandarles ${ }^{\mathrm{CVII}}$ hacer un ensayo formal en el teatro, lo hubiera notado y corregido fácilmente.

Dependiendo el progreso de la acción de que don Silvestre entienda que el Filósofo pretende a su hija ${ }^{147}$, este gran proyecto no está bien preparado, y parece un efecto de la casualidad el que Roque ${ }^{\mathrm{CVIII}}$ se lo diga, metiéndose a esta oficiosidad sin habérselo encargado. Yo suplí esto muy fácilmente con un par de versos en boca de don Felipe, en que al empezar el acto segundo le dice a su criado que esté alerta para hablar al viejo sobre lo que le han instruido antes, si halla ocasión.

Igual libertad me tomé en preparar el gran golpe del arresto y embargo del Filósofo, pues la venida del escribano parece por máquina, y el espectador, no alcanzando a presumir de dónde viene el golpe, cree es un recurso mezquino, como el que ve todos los días en los sainetes. Yo lo preparé ${ }^{\mathrm{CIX}}$ esforzando con un par de versos las amenazas del marqués al marcharse, las cuales dejan bien preparado aquel lance ${ }^{\mathrm{CX}}$.

En la orden que lee el escribano han reparado algunos, y principalmente Romero, que no está muy arreglada a la práctica legal, y me ha encargado que te ${ }^{\mathrm{CXI}}$ lo escriba. Yo de esto no entiendo, pero ${ }^{\mathrm{CXII}}$ es preciso que lo mires con mucho cuidado, porque el que te llamen mal poeta es chico pecado, pero ¡mal letrado un señor fiscal!

Viniendo ahora al proyecto de imprimirla, te conjuro por nuestra amistad que no lo hagas, porque tus enemigos han dado la más maligna interpretación a lo que se dice sobre la prisión, a las exclamaciones del Filósofo, a las palabras y conducta del alcalde de Corte, etc., asegurando que, aunque la comedia es mala en cuanto al arte, es detestable por sus principios sediciosos. $\mathrm{Y}^{\mathrm{CXIII}}$ otros, tomando el extremo opuesto, dicen que es excelente por estar escrita con todo el espíritu de un jacobino ${ }^{148}$. Esta calumnia tomará más cuerpo si se imprime en

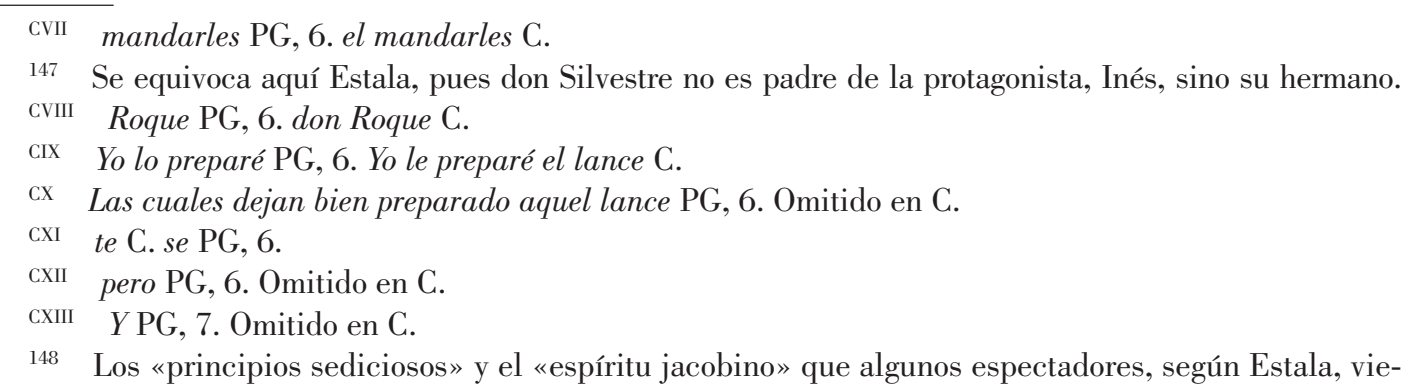
ron en la obra, se encontraban al final del tercer acto, pues en una carta sin firma dirigida a Forner sobre la recaudación de la obra se dice que «al segundo día se corrió por Madrid que se iba, de orden de la Sala, a reformar la tercera jornada, lo que ha contribuido a su celebridad». Cfr. CuETo, «Bosquejo histórico-crítico», págs. CXLII-CXLIII. Sin embargo, en el texto que finalmente se imprimió no descubrimos hoy tales propósitos, lo que ha llevado al profesor López a pensar que «o Forner prudentemente, por la alarma de Estala, modificó las últimas escenas suprimiendo pasajes que podían ser malinterpretados, o no tocó el texto, en cuyo caso hay 
las presentes circunstancias, sin acordarse de que la comedia se compuso seis años hace ${ }^{\text {CXIV }}$. Y por si ignoras lo que aquí pasa, voy a decirte algo.

Has de saber que aquel frenético Picornell ${ }^{149}$, que antes no pensaba sino en proyectos de educación para inculcar en los niños de ambos sexos las obligaciones de amor, respeto, obediencia, etc. al monarca, en catecismos monárquicos para enseñar estas importantes verdades por principios, a fin de que fuesen un contraveneno contra los sofismas y delirios de los gabachos, proyectos en que a ti y a mí se nos hizo trabajar tanto, y que yo proseguí con gusto después de tu ausencia, porque, aunque siempre miré con desprecio al tal Picornell, creí hacer un servicio a la nación, como efectivamente lo hubiera sido si se hubiera publicado aquel Catecismo ${ }^{150}$, y más que ${ }^{\mathrm{CXV}}$ él se llevara ${ }^{\mathrm{CXVI}}$ la gloria de haberlo compuesto. Pues, amigo de mi alma, el susodicho mentecato ${ }^{\mathrm{CXVII}}$ se halla preso, y dicen que es por hablar y propagar las malditas máximas de los franceses, con $^{\text {CXVIII }}$ otra porción de canalla ${ }^{151}$. Hace más de un año que yo no le veía y creí

que admitir, si estamos dispuestos a creer literalmente a Estala, que en enero de 1795 el público de Madrid reaccionaba con singular viveza a todo lo que guardaba relación, más o menos de lejos, con la libertad de expresión, las detenciones arbitrarias y el aparato coercitivo de la justicia». Cfr. López, Juan Pablo Forner, págs. 541-543. No obstante, Forner sí efectuó los cambios que juzgó pertinentes, pues en junio envía a Bernabéu un ejemplar con la comedia «ya corregida y afeitada para la impresión». Cfr. Carta dirigida a Ramón María Zuazo y recogida por LóPEZ, op. cit., págs. 646-647.

CXIV hace PG, 7. ha, C suprime todo lo que sigue hasta mentecato.

149 El mallorquín Juan Mariano Picornell y Gomila (1767-1825) era un conocido profesor de filosofía de la Universidad de Salamanca, muy interesado por las reformas educativas. El episodio al que alude aquí Estala, en el que Picornell participó, es la llamada revolución madrileña del cerrillo de San Blas, en 1795, por la que se pretendía establecer una monarquía constitucional basada en la soberanía popular. La profesora Iris Zavala conjetura que esta radical transformación ideológica de Picornell se debió a su trato con un grupo de descontentos con el sistema político español que se reunían en la Sociedad Económica de Madrid, entre los que se encontraba el conde de Cabarrús. Cfr. I. Zavala, «Cabarrús y Picornell: un documento desconocido», Cuadernos Hispanoamericanos, 234 (1969), págs. 774-782. El fracaso de este movimiento revolucionario le valió el destierro a América, pero allí ayudó activamente en el proceso independentista que se gestaba en aquellos años. No ha de olvidarse que a él se debe la traducción española de la Declaración de los Derechos del Hombre y del Ciudadano con varias máximas republicanas y un discurso preliminar dirigido a los americanos (versión del capítulo correspondiente de la Constitución francesa de 1793). Véase F. VIvo MACHO, «Juan Bautista Picornell. Más allá de la frustrada conspiración del día de San Blas de 1795», en La época de Carlos IV, págs. 1141-1155.

150 Estala y Forner colaboraron con Picornell en la composición de un Catecismo político para la instrucción de la infancia española que pretendía inculcar en la juventud el respeto por los principios de la monarquía. El manuscrito fue enviado a Floridablanca en 1787, que le comunicó el plan a Carlos III, pero hasta agosto de 1789 no se sometió el trabajo a la consideración de la Real Sociedad de Madrid. Allí se desestimó su viabilidad por oposición de Francisco Cabarrús.

CXV llevara [corrección mía] llevará PG, 7.

CXVI Y más que, «aunque».

cXVII mentecato PG, 7, mentecato Picornell C.

cXVIII con... sería el PG, 7. Omitido en C.

151 Los detenidos y condenados a muerte (si bien después les fue conmutada la pena capital por la de destierro) eran Juan Picornell y Gomilla, José Lax, Manuel Cortés Campomanes, Bernardo Garaza, Juan Manzanares, Juan Pons Izquierdo y Joaquín Villalba, todos masones. 
que ya se lo hubiese llevado el diablo o que de vergüenza por no haber podido imprimir el Catecismo y darme el dinero prometido (con el cual nunca conté) excusaba el verme ${ }^{152}$. Pero el verdadero motivo, como ha mostrado el suceso, sería el haber mudado de modo de pensar y, conociendo a fondo el mío, tan contrario y enemigo de todos los horrores de la Francia y de sus perversas doctrinas, acudiría a buscar otros de su pandilla ${ }^{153}$. En esta inteligencia ya ves cuánto te perjudicaría el que se creyese que tú eras capaz de apoyar semejantes máximas, pues ${ }^{\mathrm{CXIX}}$ por más apologías que encajases en el prólogo, tus enemigos no cesarían de calumniarte. Créeme, remite la impresión para otra ocasión, y entonces, examinando de nuevo la comedia, te diré con mi acostumbrada ingenuidad lo que pueda mejorarse en ella. Agur.

Tuyo,

Damón.

\section{Carta XX}

Madrid, mayo de 1795 (PG: XX: 33-34)

Ya habrás recibido el Diario que te envié por Bernabéu, en que se hace crítica de El filósofo ${ }^{154}$. El autor de dicha epístola se presume que es un tal Iriarte, a quien llamábamos el cura cántabro, insigne pedantón, y de quien Moratín tomó mucho para su don Hermógenes ${ }^{155}$. El Imparcial es un conocido mío, lla-

152 El proyecto de Picornell no se imprimió en formato de libro, sino que fue publicado en El Correo de Madrid entre 1790 y 1791, de lo cual no se derivó ganancia alguna que Estala pudiera cobrar.

${ }^{153}$ No deja de ser interesante esta airada actitud de Estala contra todo lo que pueda vincularlo a las nuevas ideas procedentes de Francia, pues más parece la autodefensa del que en verdad tiene algo que ocultar que la de quien se sabe libre de toda sospecha. No es improbable que nuestro helenista, aun no siendo abiertamente partidario de las opciones más radicales y revolucionarias, estuviera de alguna manera vinculado a los grupos que criticaban la alianza de la monarquía absoluta con la Inquisición, críticas que en absoluto podía hacer explícitas en estos momentos. Deja, por tanto, claro que no tiene nada que ver con Picornell y el resto de los condenados, pero hemos de recordar que, por ejemplo, uno de ellos, Juan Pons Izquierdo, redactor del Correo de Madrid y maestro de francés y humanidades, no sólo es amigo de Moratín y Forner (ver Epistolario, carta 31), sino que es uno de los miembros de la Academia poética de los pastores del Manzanares, organizada en la trastienda de Gabriel Sancha y a la que Estala tiene especial interés en pertenecer (véase carta 9).

cxix pues... calumniarte PG, 7. Omitido en C.

154 El 28 de abril de 1795 se publica en el Diario de Madrid una carta firmada por El Ingenuo en la que se critica duramente la obra de Forner, a la que el autor imputa no sólo defectos poéticos, sino errores relacionados con el campo de la judicatura. La carta del Ingenuo era una respuesta a la escrita anteriormente por El Imparcial, que había elogiado brevemente la obra de Forner en una de las cartas cruzadas con un tal Philopatro, dentro de una polémica que se venía manteniendo en el Diario desde marzo sobre el estado de nuestro teatro.

155 Pérez de Guzmán apunta en su edición que se trata de Tomás de Iriarte, pero eso es imposible porque el fabulista era canario (no cántabro) y había muerto en septiembre de 1791. La crítica siempre ha 
mado Cienfuegos, una abate altísimo, que no sé si conocerías ${ }^{156}$. El censor de los Diarios es el padre Fernández, de san Felipe el Real, autor de la Crotalogía ${ }^{157}$. Yo no he podido todavía tomar la pluma en defensa tuya, porque he estado componiendo el maldito Mercurio, y haciendo una infinidad de representaciones, cartas y memoriales para Bernabéu, a quien su director quiere amolar ${ }^{\mathrm{CXX}}$ y él se ha empeñado en amolar al tal director. Fuera de esto, yo no tengo la comedia ni puedo haber a las manos otra copia que la que tiene mi paisano Romero, la cual está como salió al principio, sin las correcciones que después has hecho.

El tal epistoli-gafo ${ }^{\mathrm{CXXI}}$ es el compendiador de todo lo que se ha dicho contra tu comedia, y por consiguiente es necesario que te esmeres en hacerle pedazos; pero es preciso que convengamos en el modo de hacer la defensa. Lo más acertado me parece será el que escribas una carta para el Diario, no muy larga, pero aunque haya para tres Diarios, no importa, que yo haré se inserte, porque el administrador del Diario es amigo mío. Además de esto, cuando la imprimas, que ahora ya es preciso que sea pronto, debes ponerla un prólogo de galeato ${ }^{158}$, en que con más extensión sacudas a toda esa canalla, sin dejar de sacudir algunos

conjeturado que Moratín se inspiró en Cristóbal Cladera para construir este personaje de La comedia nueva (1792), pero sin duda debió tener en cuenta otras referencias, como aquí apunta Estala. Por mi parte, no he podido identificar a la persona que se oculta tras El Ingenuo. Según Gil de Lara, en su «Epístola a Andrés» (1805), Moratín llama «don Hermógenes» o «Pedancio» a José Luis Munárriz. Cfr. A. Derozier, Manuel José Quintana y el nacimiento del liberalismo en España, Madrid, Turner, 1978, pág. 302.

156 Pérez de Guzmán señala que se trata de Nicasio Álvarez de Cienfuegos, pero éste no era abate. Según creo, Estala miente aquí a Forner, pues quien en verdad se ocultaba tras El Imparcial era precisamente el propio Estala, que quizá no quería que su amigo descubriese que su defensa del Filósofo no había sido lo efusiva y laudatoria que hubiera cabido esperar. He intentado seguir todo el proceso y desvelar los malentendidos que surgieron, en mi artículo «En desagravio de Estala. A propósito de una crítica contra El filósofo enamorado de Forner en el Diario de Madrid (1795)», Cuadernos de Estudios del Siglo XVIII, 10 y 11 (2000-2001), págs. 17-41.

157 Juan Fernández de Rojas (1750-1819) era el autor de una sátira contra los modos de exposición del saber que estaban a la moda, titulada Crotalogía o ciencia de las castañuelas (1792). Fue identificado como el crítico que cada mes, y bajo el seudónimo de El censor mensual, hacía juicios y valoraciones de los trabajos literarios y cartas críticas que se publicaban en el Diario de Madrid. Pero, como he demostrado en otro lugar, El censor mensual no era Fernández de Rojas, sino Pedro Estala. Para este asunto, véase mi artículo «Pedro Estala como “censor mensual” en el Diario de Madrid (1795-1798)», Revista de Literatura, LXII, 124 (2000), págs. 327-346. Aquí el helenista manchego responde a Forner sobre la identidad del «censor de diarios», esto es, la persona encargada por el juez de imprentas para autorizar lo que se iba a publicar o no en cada número del periódico.

CXX Amolar, en su uso familiar y figurado, «fastidiar, molestar con pertinacia» (DRAE).

CXXI epistoli-gafo, neologismo formado a partir de la palabra epistológrafo, «persona que se ha distinguido en escribir epístolas» (DRAE), en la que se ha sustituido el sufijo culto -grafo por el adjetivo gafo, que gafa, esto es, que transmite o comunica mala suerte a alguien o a algo.

158 Galeato, «aplícase al prólogo o proemio de una obra que la defiende de los reparos y objeciones que se le han puesto o se le pueden poner» (DRAE). Forner escribirá un prólogo titulado «Apología del vulgo con relación a la poesía dramática», que antepondrá al Filósofo enamorado cuando esta obra se imprima (Madrid, Fermín Villalpando, 1796, págs. III-XXXVII). 
buenos palos a don Santos, que es el que más declama contra ellos. Si quieres que yo me encargue de alguna parte de esta defensa, avísame el qué y el cómo y el cuándo; y de cualquier modo, yo tengo intención de dar algunos buenos palos al tal mentecato.

Es increíble la avilantez de los pedantuelos que bullen en este Diario de Madrid: uno asegura que nuestro teatro es el más perverso del mundo y nuestros actores los más incapaces; otro afirma que no tenemos Parnaso y que nuestros mejores poetas del siglo XVI son indignos de este nombre ${ }^{159}$. Yo estoy hecho un poltrón apático y siento más tomar la pluma que el que me saquen una muela. Pero, a pesar de mi poltronería, voy a sacudirles de fuerte.

Se dijo aquí que venías y yo no te veo venir. Mal haces en ser tan poltrón, pues si no haces un viaje, jamás se acordarán de sacarte de entre esos caribes. En las circunstancias actuales servirías de mucho por aquí y al mismo tiempo medrarías. Yo vegeto y no pienso en más que en pasar mi vida con el menor trabajo e incomodidad posibles. Pásalo bien y manda a tu

Damón

$$
*
$$

Después de escrita esta he recibido la tuya y apruebo todo tu proyecto: la comedia debe imprimirse y pronto y con todas las armas ofensivas y defensivas. Sobre el Diario ya ves lo que te digo: si es tan larga tu respuesta, no querrán los censores que se inserte, porque nunca quieren que pase un discurso o carta de más de tres Diarios y, además, siendo tan francos ${ }^{\text {CXXII }}$ para los fatuos que impugnan, suelen ser muy escrupulosos para las respuestas en que more nostro ${ }^{\text {CXXIII }}$ se les cubre de ridículo. Si se puede reducir tu respuesta a estos términos, envíala, que yo haré se ponga. Pero como sería lástima que estos virotes de censores metiesen su hoz y te podasen lo mejor, creo que convendría la pusieses por apéndice de la comedia y yo, en la respuesta que pienso por dar al tal Ingenuo, después de hacerle ver por mayor que es un mentecato, le remitiré a tu apéndice, con lo cual el público entrará en curiosidad y la respuesta saldrá entera y con toda su dignidad.

159 En realidad, se trata del mismo corresponsal, Manuel Pardo de Andrade, que, camuflado tras diversos seudónimos (Philopatro, El Desengañador, El Arrogante...), envía al Diario de Madrid varias cartas en las que afirma, en tono provocador, precisamente lo que aquí le comenta su amigo a Forner. Las respuestas de Estala a la provocación dan lugar a jugosas polémicas durante los meses de abril y mayo. Cfr. M. PARDO DE Andrade, Los artículos del Diario de Madrid (1794-1800), ed. de M. ${ }^{\text {R }}$. Saurín de la Iglesia, La Coruña, Fundación Pedro Barrie de la Maza, 1989; y mi edición de Estala Ribera, Prefacios y artículos de crítica literaria.

CXXII Franco, «de acceso libre y sin impedimento» (DRAE).

CXXIII More nostro, «según nuestra costumbre». 


\section{Carta XXI}

Madrid, después del 24 de junio de 1795 (PG, XVIII: 28-30)

Eres el cuadrúpedo más brutal que hay sobre la tierra. ¿Quién te ha dicho que yo me entibio en tu amistad? Y ¿cómo has podido soñar que el que tu comedia fuese mala o buena podía influir en mi estimación para contigo? Moratín ha hecho excelentes comedias y yo le detesto de todo mi corazón; la tuya pudiera ser peor que las de todos los Comellas ${ }^{160}$, y no por eso se disminuiría un punto mi amistad. Anda, que eres un jumento.

Ahora, ya no negaré que a veces me enrabio contra ti, pero no por comedias, ni cosas semejantes; pues ¿no es bueno que he de estar yo aquí y todas tus cosas las he de saber por otros? Que imprimes tu Contestación ${ }^{161}$ por medio de yo no sé quién, a quien no he visto la cara, aunque yo he sido el censor de ella $^{162}$. ¿Y qué? ¿Para tener un ejemplar se lo he de pedir a Bernabéu? Viene la comedia a mi censura, la despacho al día siguiente, y en quince días no parece $^{\mathrm{CXXIV}}$ alma nacida por ella, hasta que yo mismo tengo que llevársela al secretario del juez de imprentas ${ }^{163}$. ¿Te parece que no sobra motivo para enviarle a un sitio feo, fiscal?

Pues vamos a la impresión de la comedia y me dice Bernabéu que ha de imprimirse como la de El viejo y la niña, y luego que ha de ser en octavo pro-

160 Alusión a Luciano Francisco Comella, autor de más de cien obras de teatro de todos los géneros dramáticos, entre las que destacan sus comedias lacrimosas y dramas heroicos, con las que tuvo gran éxito. En 1790 estrenó El sitio de Calés, al parecer el modelo para El gran cerco de Viena, la obra ficticia que se representa durante la trama de La comedia nueva, de Leandro Moratín.

161 El profesor López señala que no ha podido ver esta primera impresión de la Contestación de Forner al Ingenuo en defensa de su comedia. Lo que hoy conocemos en la reimpresión de Cádiz: Carta del Diario de Madrid de 28 de abril impugnando la comedia del Filósofo Enamorado, a la que sigue una defensa de la expresada crítica, por un amigo del autor de la comedia, Cádiz, Manuel Ximénez Carreño, 1795. Cfr. LóPEz, Juan Pablo Forner, pág. 544, n. 103.

162 Forner publica su Contestación a través de Ramón María Zuazo, el representante en Madrid de la Sociedad Económica de Sevilla, a quien en una carta fechada el 23 de mayo de 1795 le dice que no cuente con Estala para nada, de manera que las decisiones sobre el tamaño o el número de ejemplares las tome consultando al impresor Cano, su amigo. Zuazo no debió demorarse demasiado en llevar a cabo las diligencias oportunas, pues el 6 de junio Forner ya sabe que la Contestación está imprimiéndose: «Me alegro que ya esté en prensa el latigazo al pedantón del Diario y si Estala ha andado en esta danza (como es de creer), se ha llevado fiero chasco en no haberla visto antes de imprimirse, como lo había dispuesto mi candidez». Cfr. López, Juan Pablo Forner, pág. 643.

CXXIV Parecer, «aparecer o dejarse ver alguna cosa» (DRAE).

163 Una vez corregida, Forner envía su obra a Francisco Bernabéu el día 24 de junio de 1795, junto con el mencionado prólogo. La obra es presentada al Consejo de Castilla para los trámites de censura y quiere el destino que llegue a manos de Estala, colaborador de la citada institución, que firma un informe favorable. 
longado ${ }^{164}$. Ven acá, hombre del diablo, ¿qué se entiende Bernabéu de impresiones, ni de octavos, ni de folios? Si el tamaño ha de ser octavo prolongado, ¿qué figura hará la letra de El viejo y la niña? Conque si se ha de poner en este tamaño, es preciso que la letra sea una lectura chica como la de mi Edipo, y entonces te costará doble, porque el papel es muy caro y no la podrás dar por seis reales ${ }^{\mathrm{CXXV}}$. Lo que yo juzgo es que debe ser en todo como El viejo y la niña y entonces, saliéndote más barata la impresión, ganarás más y tendrá más despacho $^{\text {CXXVI }}$ a peseta $^{165}$ que del otro modo a seis reales.

Ya ves que tengo razón en quejarme de ti, pero, al mismo tiempo, te advierto que tengo mis presunciones de que no falta quien procura que nos enemistemos (no sé por qué) y quizá te habrán escrito algo que te haya indispuesto contra mí. Tú cree lo que quieras, pero sabe que en mí no hay mudanza ${ }^{166}$. También ha habido quien provoque a don Santos ${ }^{167}$ contra ti y contra mí y luego han venido a contarme que el tal dómine había dicho mil blasfemias contra mí; pero, averiguado el caso, no hubo más que el provocar a este jumento diciéndole que tú y yo estábamos escribiendo contra él y decir él que se cagaba en nosotros sin meterse en más dibujos. Por lo que hace a la carta de El Ingenuo, es imposible que sea suya, pues he visto otra del mismo Ingenuo dirigida al Diario, de la misma letra y estilo que la primera, contra tu contestación, y en ella manifiesta que es un leguleyo practicón, según la erudición rabulística ${ }^{168}$ que encaja, y lo que es sobre el mérito poético de la comedia no habla palabra; conque, ya ves que el dómine Santos lo hubiera hecho al revés. Yo he procurado que no se ponga en el Diario la tal carta, porque no prueba nada y está llena de desvergüenzas que sería necesario castigar a garrotazos. Si puedo lograr que me la dé el diarista, te la enviaré y verás que tengo razón en mi juicio de que es parto de algún rabulón.

164 Estala se enfada porque se trata de dos sugerencias contradictorias: la primera edición de El viejo y la niña (Madrid, Benito Cano, 1790) iba en octavo $(16 \mathrm{~cm})$, de manera que si Forner quiere que la edición de El filósofo sea igual, no puede pedir que se imprima en octavo prolongado $(18$ '5 cm) pues, como explica más adelante, en este formato la letra de El viejo quedaría ridícula.

CXXV «por menos de seis reales».

CXXVI Más despacho, «mejor venta».

165 Una peseta equivale a cuatro reales.

166 Efectivamente, en una carta de mayo de 1795, Ramón María Zuazo le había dicho a Forner que El ingenuo era precisamente su amigo Estala. Al parecer, Bernabéu también confirma las sospechas de Forner, como se desprende de las cartas que en estas fechas el fiscal se cruza con Zuazo. Pueden leerse en el apéndice del trabajo de LóPez, Juan Pablo Forner, pág. 642 y ss. Conjeturo que las sospechas de Zuazo y de Bernabéu derivan del hecho de que Estala no participara en la polémica abiertamente, sino camuflado tras un seudónimo, que los maliciosos y no avisados automáticamente identificaron con el Ingenuo aunque, como ya creo haber demostrado, el helenista se ocultaba tras el Imparcial.

167 Santos Díez González.

168 Rábula, «abogado indocto, charlatán y vocinglero» (DRAE). 
Ya sabrás por Bernabéu que borré en el prólogo aquella pulla contra los moralistas, porque si éstos levantaban el grito, según están las cosas, toda tu golilla no te libraría de un mal rato ${ }^{169}$. También borré cuatro versos en que hablabas demasiado claro contra los matrimonios que se usan ${ }^{170}$, materia sumamente delicada y que basta insinuarlo, como lo haces en aquel mismo lugar. Si llevas a mal estas correcciones, no me importa. Yo, de cuya amistad sospechas, miro más por tu honor que tú mismo.

La impresión de tu comedia juntamente con la Contestación acabará de manifestar al público la incapacidad y malignidad del Ingenuo por lo que hace a la parte poética; yo te la fío. Por lo tocante a lo del juez, he preguntado a un abogado amigo y me ha dicho que tienes razón, pero que para tapar la boca a tus enemigos, que se agarran de aquel auto y gritan que es un atropellamiento, se podía mudar el auto en un simple aviso extrajudicial del juez, para que el Filósofo le esperase en su casa para averiguar cierta delación, etc. ${ }^{171}$ Tú sabrás si en esto hay inconveniente y me avisarás.

He visto tu Dedicatoria, la cual parece no agrada al mecenas, y hace bien, porque está demasiado buena y en nada se parece a las que están acostum-

169 Forner no aceptó esta corrección de Estala, pues en la versión del «Prólogo» que vio la luz en 1796 se lee: «No hay que buscar en otras fuentes la depravación de nuestro teatro. Considerado éste como un mero instrumento de licitud ambigua para dar al pueblo tal entretenimiento, en el concepto de los moralistas pasó por abominable; en la opinión de los sabios pasó por ocupación fútil; y los que pudieran saber las reglas por la vasta comprensión de sus estudios, ni las recomendaron, ni las practicaron». Cfr. "Apología del vulgo con relación a la poesía dramática», en La escuela de la amistad o El filósofo enamorado, Madrid, Fermín Villalpando, 1796, pág. v.

170 Se trata de los matrimonios de conveniencia y por dinero; en muchos casos, los dos cónyuges gozaban de extrema libertad, hasta el punto de que la esposa podía tener un amante «reconocido» por el marido, al que se llamaba cortejo y que la visitaba, la acompañaba a hacer compras o de paseo. Véase C. MarTín GaITe, Usos amorosos del siglo XVIII español, Barcelona, Anagrama, 1988. Las alusiones a este asunto están diseminadas a lo largo de toda la obra, pero véanse sobre todo las páginas 134-135 de la edición de 1796. Que Forner se mostrara especialmente agresivo contra estos matrimonios tan tolerantes quizás pueda deberse a una experiencia personal. En una de las cartas que envía a su protector, Francisco Pérez de Lema, dice a propósito de su nueva vida matrimonial: «Su buen parecer excitó la curiosidad de una juventud desenvuelta que quiso arrojarse a mi casa como para tentar el camino de introducir en ella la infamia y el desorden. Sin más espantajo que lo respetable de mi aspecto, la severidad concisa de mis expresiones, las alusiones festivas de mi humor todavía satírico y la indiferencia decorosa de la amabilísima joven, huyó la turba atolondrada, y en Sevilla es hoy mirada mi casa con el respeto que se debe a un santuario del amor conyugal». Cfr. Aguilar PIÑAL, «La boda de Forner», p. 542.

171 Estala se refiere a uno de los reparos del Ingenuo, que en su carta decía: «Y finalmente [...] recomiendo al juicio de Vmd. la conducta de un juez que se propone como modelo de integridad, el cual, por una simple y verbal acusación, hace secuestrar la persona y bienes del Filósofo y, dado este paso, procede a la averiguación del delito que se le imputa, que es lo mismo que proponer por ejemplar de justificación a un magistrado inicuo, y tan ignorante como el autor que, queriendo dar lecciones de judicatura, no sabía ni aun por dónde se debe empezar un juicio criminal». Cfr. Diario de Madrid, núm. 113, martes 28 de abril de 1795, pág. 487. 
brados a admitir ${ }^{172}$. Tu debes insistir porque se ponga $u t$ iacet ${ }^{\mathrm{CXXVII}}$ y si no que envíe a componer a su gusto otra a Italia. De cualquier modo, es menester que este punto se determine pronto de un modo o de otro, porque la impresión va a empezarse, luego que tú resuelvas acerca del tamaño y de la letra. Yo correré con las pruebas y con la dirección, para que no salga con mentiras y en forma de sermón, como la Contestación.

Sobre la comedia El ateísta te advierto que no sé si podrías ${ }^{\mathrm{CXXVIII}}$ lograr que se represente ${ }^{173}$, porque estas gentes se han empeñado en que no se ha de hablar ni bien ni mal de estas materias, porque sin duda no convendrá que, introduciéndose tanto veneno por tantas partes y de tantos modos, haya contravenenos que impidan sus estragos. Deseo mucho ver una y otra obra.

Tenía escrito un discursote para el Diario que acompañase a la publicación de la Contestación, pero, en vista de lo que me dices, lo he reducido a cuatro palabras, anunciando que destruye todos los sofismas del Ingenuo. Este ha vuelto a repetir otra carta quejándose de que no se haya publicado su primera, pero esta tendrá el mismo destino que la otra. Vinagrillo me ha dicho que la semana que viene te enviará las Exequias, que está acabando de leer Vargas ${ }^{174}$. Adiós.

Damón.

172 Forner ofrece El filósofo enamorado a Luis Godoy. En la «Epístola dedicatoria» habla de los viejos tiempos de la juventud, cuando él mismo y Mirtilo alegraban con su poesía al hoy favorecido con el poder. Entre los elogios que le brinda destaca la alusión al exquisito gusto literario de don Luis, que no se ha dejado arrebatar por los ingenios vulgares, sino que ha apoyado a los grandes poetas, es decir, a él y a Moratín, con cuyo arte van a inmortalizar el nombre de la patria. Como vemos, si algo distinguía al fiscal extremeño no era su modestia o humildad.

CXXVII Ut iacet, «como aparece», «tal como está redactada».

CXXVIII podrías [corrección mía] podías PG, 30.

173 Era esta una comedia en la que Forner combatía el enciclopedismo, al decir de don Marcelino Menéndez Pelayo, Historia de los heterodoxos españoles, ed. de E. Sánchez Reyes, Santander, CSIC, 1946-1948, pág. 605. No se llegó a representar nunca. No aparece en la bibliografía de Aguilar Piñal, pero sí la recoge J. Herrera Navarro, Catálogo de autores teatrales del siglo XVIII, Madrid, FUE, 1993, págs. 187-189.

174 Dado que no puede ser una referencia al marino José Vargas Ponce, enemigo declarado de Forner, conjeturo la posibilidad de que se trate de Ramón Pisón y Vargas, abogado de los Reales Consejos y vecino de Santo Domingo de la Calzada; poeta de medio pelo, publicaba fábulas en el Diario de Madrid con el seudónimo de Román de Pinos. Era hermano de Juan Antonio Pisón y Vargas, autor de «La perromachia» (1786), poema paródico sobre los amores de unos perros. Cfr. Aguilar Piñal, Bibliografía, t. VI, pág. 423. En 1798 envió a este periódico varios poemas satíricos contra Juan Bautista Arriaza, enemigo de Estala desde que éste censurara y pusiera reparos a sus poesías. Cfr. Aguilar Piñal, Índice de las poesías publicadas en los periódicos españoles del siglo XVIII, Madrid, CSIC, 1981, pág. 329. 